Article

\title{
Effect of Temperature on the Size of Sedimentary Remains of Littoral Chydorids
}

\author{
János L. Korponai ${ }^{1,2,3, *(D)}$, Csilla Kövér ${ }^{4}$, Charo López-Blanco ${ }^{5}$, István Gyulai ${ }^{6}$ D, László Forró ${ }^{7}$, \\ Ana Katalinic ${ }^{8}$, Mirva Ketola ${ }^{9}$, Liisa Nevalainen ${ }^{10} \mathbb{D}$, Tomi P. Luoto ${ }^{10} \mathbb{D}$, \\ Kaarina Sarmaja-Korjonen ${ }^{11}$, Enikő K. Magyari 12,13,14 , Jan Weckström ${ }^{15} \mathbb{D}$, István Urák ${ }^{2}$, \\ Edit Vadkerti ${ }^{1}$ and Krisztina Buczkó ${ }^{14,16,17}$ (D)
}

1 Department of Water Supply and Sewerage, Faculty of Water Science, University of Public Service, Bajcsy-Zs. utca 12-14, 6500 Baja, Hungary; vadkerti.edit@uni-nke.hu

2 Department of Environmental Sciences, Sapientia Hungarian University of Transylvania, Calea Turzii nr. 4, 400193 Cluj-Napoca, Romania; urakistvan@gmail.com

3 MTA-PE Limnoecology Research Group, University of Pannonia, Warta Vince u. 1, 8200 Veszprém, Hungary

4 Food and Wine Research Center, Eszterházy Károly University, Leányka u. 6, H-3300 Eger, Hungary; csilla.kover@gmail.com

5 Department of Animal Ecology \& Systematics, Justus Liebig University, Heinrich-Buff-Ring 26-32 IFZ, D-35392 Giessen, Germany; charo.lopez-blanco@allzool.bio.uni-giessen.de

6 Department of Hydrobiology, University of Debrecen, Egyetem tér 1, H-4032 Debrecen, Hungary; istvan.gyulai@gmail.com

7 Department of Zoology, Hungarian Natural History Museum, Baross u. 13, 1088 Budapest, Hungary; forrolotzi@gmail.com

8 Public Institution Nature Park 'Vransko Jezero', Kralja P. Svacica 2, 23210 Biograd na Moru, Croatia; ana.katalinic@gmail.com

9 The Lake Vesijärvi Foundation, Askonkatu 9 C, 15100 Lahti, Finland; mirva.ketola@vesijarvi.fi

10 Ecosystems and Environment Research Programme, Faculty of Biological and Environmental Sciences, University of Helsinki, Niemenkatu 73, FI-15140 Lahti, Finland; liisa.nevalainen@helsinki.fi (L.N.); tomi.luoto@helsinki.fi (T.P.L.)

11 Department of Geosciences and Geography, University ofHelsinki, P.O. Box 64, 00014 Helsinki, Finland; Kaarina.Sarmaja-Korjonen@helsinki.fi

12 Department of Environmental and Landscape Geography, Eötvös Lorand University, Pázmány Péter stny. 1/C, H-1117 Budapest, Hungary; emagyari@caesar.elte.hu

13 MTA-MTM-ELTE Research Group for Paleontology, Pázmány Péter stny. 1/C, H-1117 Budapest, Hungary

14 Centre for Ecological Research, GINOP Sustainable Ecosystems Group, Klebelsberg Kuno 3, H-8237 Tihany, Hungary; krisztina@buczko.eu

15 Ecosystems and Environment Research Programme, Faculty of Biological and Environmental Sciences and Helsinki Institute of Sustainability Science (HELSUS), University of Helsinki, P.O. Box 65 (Viikinkaari 1), FI-00014 Helsinki, Finland; jan.weckstrom@helsinki.fi

16 Department of Botany, Hungarian Natural History Museum, Baross u. 13, 1088 Budapest, Hungary

17 MTA Centre for Ecological Research, Danube Research Institute, Karolina út 29, H-1113 Budapest, Hungary

* Correspondence: korponai.janos@uni-nke.hu

Received: 28 March 2020; Accepted: 30 April 2020; Published: 6 May 2020

check for updates

\begin{abstract}
The body size of aquatic invertebrates is, to a great extent, dependent on ambient temperature, but size distributions are also determined by other factors like food supply and predation. The effect of temperature on organisms is formulated in the temperature-size hypothesis, which predicts a smaller body size with increasing temperature. In this study, the effect of temperature on the subfossil remains of three littoral Cladocera (Alona affnis, A. quadrangularis, and Chydorus cf. sphaericus) was investigated. Exoskeletal remains of these species can be found in large numbers in lacustrine sediments and over a wide north-south range in Europe. The total length of both headshield and postabdomen for $A$. affinis and A. quadrangularis and carapace length for $C$. cf. sphaericus were measured to observe their response to changes in latitude and temperature. A different response
\end{abstract}


to ambient temperature in the growth of body parts was observed. The size of the headshields of both Alona species and of the carapace of Chydorus was significantly larger in colder regions as opposed to warm ones. It turned out that the postabdomen was not a good predictor of ambient temperature. While the sizes of all remains increased with latitude, the sizes of the Alona remains was smaller in the mountain lakes of the Southern Carpathians than in other cold lakes, in this case in Finland, a fact indicative of the importance of other factors on size distribution. This study demonstrates that a morphological response to climate is present in littoral cladocerans, and, therefore, changes in the length of headshield and carapace may be used as a proxy for climate changes in paleolimnological records.

Keywords: subfossil remains; size distribution; latitudinal pattern; temperature effect; benthic chydoridae; cladocera

\section{Introduction}

Crustacean cladocerans (Branchiopoda) are functionally adapted to diverse microhabitats in lakes. Some species live in open water (pelagic species, according to the strict definition of zooplankton), whereas others are attached to macrophytes (epiphytic) or abiotic surfaces, such as lake beds covered with silt, pebbles or sand. Cladocerans occupy a central position in the food web; their abundance and assemblage depend on bottom-up (food supply) and top-down (predation pressure) forcing to the same degree as on habitat availability. Therefore, any changes in cladoceran community composition and functional traits may well indicate changes in the prevailing environmental conditions [1]. The body size of cladocerans is a functional trait of great importance, because it has an influence on resource use, and may indicate predation patterns. This is because large-bodied zooplankton have greater grazing rates, they filter a wide range of food particles, and hence exert a stronger top-down effect on resources than small-bodied zooplankton do. It should also be noted that a larger body size tends to make them vulnerable to vertebrate predators, while a smaller size is preferred by invertebrate predators [2].

Both seasonal and latitudinal patterns can be observed in the body size distribution of zooplankton [3-5]. In warm water, the body size of zooplankton is generally smaller than that of those in cold water, and consequently zooplankters are larger in various waters in the cold season or in lakes at higher latitudes and/or altitudes, e.g., [5-9]. The direct effect of temperature on body size can be masked by other environmental factors that are related directly or indirectly to temperature, not to mention the fact that predation also has a significant influence on body size spectra [10]. In earlier studies where the relationship between planktonic cladoceran body size and latitude and temperature has been examined $[5,11]$, the results have shown that the body size of planktonic cladocerans declines with temperature and increases with latitude. This decrease in body size in relation to temperature has also been found in littoral cladoceran species [12] and in the majority of ectotherm organisms [13,14].

Paleolimnological studies focus on the remains of organisms (e.g., algal pigments, chrysophyte cysts, diatoms, aquatic pollen, invertebrates and fish) and their use as proxies for paleoenvironmental reconstructions [15]. Due to taphonomic processes and the selective preservation of organisms and their remains, a certain degree of bias can be observed reconstructed communities are compared to modern ones [16-19]. Cladocerans are one of the most important paleolimnological proxies for discovering the trajectory of environmental changes [20]. Besides the species composition of cladoceran communities, their size structure also responds to changes in environmental conditions [21-27]. To date, comprehensive limnological studies of cladoceran body size distribution have concentrated on planktonic species [5,11], while studies of littoral habitats have revealed the horizontal migration of zooplankton between pelagial and littoral environments [28]. Although macrophytes provide shelter against pelagic predators, predation risk may nonetheless remain high due to the high abundance of invertebrate predators, and fish, which use the littoral bed as a way of avoiding 
predators [29]. Moreover, the density of plants also affects the predation capability of fish and invertebrate predators $[30,31]$. Despite the fact that the denser the macrophyte coverage, the better the refuge they offer, juvenile fish and invertebrates tend to suppress zooplankton communities in littoral zones/environments [32-34]. Furthermore, the structure of littoral zones affects the species distribution of littoral cladocerans, since cladocerans effectively share resources, allowing the co-existence of a high number of species [35-37]. Analyzing fish gut content, Adamchuk [36] demonstrated the high degree of selectivity in various fish species, and that fish generally prefer large-bodied littoral cladocerans. Basińska et al., [38] found the body size of littoral cladocerans living among macrophytes to be larger than in that of those in open water, and ascribed this to lower predation pressure. Predation on cladocerans in the littoral zone follows complex patterns. Predation by fish is more important in environments with low turbidity, since they may be regarded as generally visual predators, while invertebrates, which detect their prey by visual and tactile means, become an important factor in structuring littoral cladoceran communities in turbid environments $[10,31]$. The thickness of the carapace can also be seen as a defensive morphological trait against invertebrate predation [39-41].

Rizo et al. [42] investigated patterns of distribution and variability of body size among freshwater Cladocera taxa across different taxonomic levels, geographic distributions and habitat associations. They found that cladoceran body size is a phylogenetically conserved trait, but the observed variation and the varying means between biogeographical regions also suggests the effect of climate on size variability in cladocerans. This factor explains the high degree of the variance observed in size spectra in particular regions as a product of habitat variability, resource availability and the effect of predators. The same research also found that substrate-associated littoral species were smaller than to planktonic ones. They concluded that the smaller body is an adaptation for survival in the presence of high numbers of predators and low oxygen concentrations in preferred habitats.

In this study, the relationships between the size of sedimentary chydorid remains preserved in surface sediments and temperature at a large geographical scale from south to north of Europe are examined. Based on both correlation of the size of body parts with environmental conditions [23] and Atkinson's rule [13,14], the hypothesis that the mean size of chydorid remains will be larger in cold environments is adopted. In this hypothesis, there is an a priori assumption that benthic chydorids are less sensitive to top-down effects than planktonic species, and that this, in turn, highlights the temperature effect on the body size distribution. The focus is on the dominant chydorid species (Alona affinis (Leydig), Alona quadrangularis (O.F. Müller) and Chydorus cf. sphaericus), because the occurrence of their remains in sediments was frequent enough throughout the dataset to make statistically adequate measurements possible.

\section{Materials and Methods}

\subsection{Study Sites}

For the analysis, lakes in Finland, Hungary, Romania, Croatia and Spain were selected. The distribution of these lakes covers wide latitudinal and climatic gradients across Europe (Figure 1; Table 1), from $40^{\circ} \mathrm{N}$ in Spain to $70^{\circ} \mathrm{N}$ in Finland. This latitudinal gradient also reflects a temperature gradient: the yearly average temperature in the most southern lake is $10.8{ }^{\circ} \mathrm{C}$ [19], while in the northernmost lake it is $-1.9^{\circ} \mathrm{C}$ [43]. The surface sediments of the lakes were sampled by means of sediment cores taken from the deepest part of the lakes, using gravity, piston and Russian peat corers. The uppermost portion of the sediment $(0-1 \mathrm{~cm}$, or in the case of very soft sediments, $0-2 \mathrm{~cm})$ was used for the analysis. The exact sedimentation rate for the lakes was not known, but it was assumed that the uppermost centimeter represented a decadal time span, with the exception of Lake El Tobar (Spain). A short core was assessed from El Tobar, since it has very high accumulation rates, and the core represented several recent decades [19]. Additionally, sediment traps were also used at Lake Balaton [44]. In Finland, the sampling was conducted between 2003 and 2013 in winter, while at the other locations, it was performed between 2010 and 2014 in summer. 


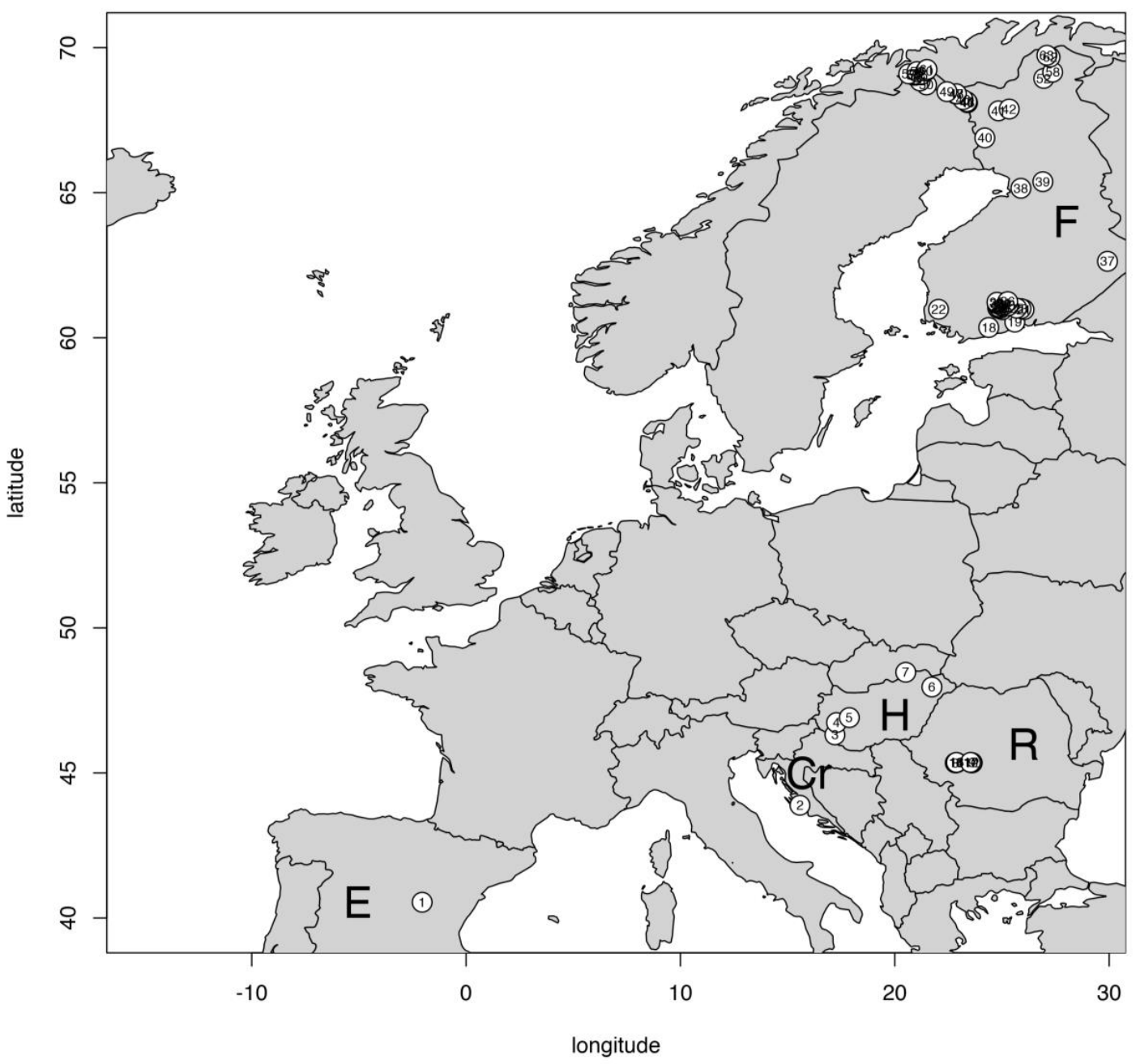

Figure 1. Location of the lakes in the study across Europe (Cr: Croatia, E: Spain, F: Finland, H: Hungary, R: Romania).

Table 1. Lakes, latitude, depth, region, temperature.

\begin{tabular}{|c|c|c|c|c|c|c|}
\hline Lakes & Latitude & $\begin{array}{l}\text { Altitude } \\
\text { (m a.s.1.) }\end{array}$ & $\begin{array}{l}\text { No. of } \\
\text { Lakes * }\end{array}$ & $\begin{array}{c}\text { Depth } \\
\text { (m) }\end{array}$ & Region & $\begin{array}{l}\text { Temp. } \\
\text { Regime }\end{array}$ \\
\hline Finland & $60-70^{\circ} \mathrm{N}$ & 39-1009 & 46 & $0.5-25$ & Nordic & cold \\
\hline Hungary & $46^{\circ} \mathrm{N}$ & $104-384$ & 5 & 3.5 & Southern & warm \\
\hline $\begin{array}{c}\text { Romania } \\
\text { (South-Carpathians) }\end{array}$ & $45.34-45.36^{\circ} \mathrm{N}$ & $1909-2129$ & 10 & $2.5-30$ & $\begin{array}{l}\text { Southern } \\
\text { Mountain }\end{array}$ & cold \\
\hline Croatia (Lake Vrana) & $43^{\circ} \mathrm{N}$ & 0 & 1 & 2.8 & Southern & warm \\
\hline Spain (El Tobar) & $40.5^{\circ} \mathrm{N}$ & 1250 & 1 & 20 & Southern & warm \\
\hline
\end{tabular}

Mean July air temperature data were used as a proxy for the water temperature of the lakes, since mean air temperature and epilimnetic water temperature correspond most closely in July $[45,46]$. Mean July temperatures were extracted from the WorldClim database at a resolution of 30 arc seconds $\left(1 \mathrm{~km}^{2}\right)$ using dismo R packages [47-49].

\subsection{Subfossil Analyses}

For the analysis of subfossil cladoceran remains, between 2 and $8 \mathrm{~g}$ of sediment were subsampled and treated with $250 \mathrm{ml}$ of $10 \% \mathrm{KOH}$ solution, heated to $80{ }^{\circ} \mathrm{C}$ and kept at that temperature for at least $1 \mathrm{~h}$, following the standard protocol for fossil Cladocera analysis [50]. Subsamples were gently stirred 
with a plastic rod to deflocculate all organic matter without damaging the remains, and sieved through a $65-\mu \mathrm{m}$ mesh with running tap water. Quantitative slides were prepared by pipetting 100-200 $\mu \mathrm{L}$ of each subsample on a microscope slide, and these were mounted using glycerol jelly stained with safranin. At least 20-30 headshields and postabdomens of Alona affinis and A. quadrangularis, and c. 30 carapaces of Chydorus cf. sphaericus were measured under a microscope at $100 \times$ and $200 \times$ magnifications to an accuracy of $1 \mu \mathrm{m}$ using microphotography. Four morphological characteristics of the headshield (Figure 2a (headshield: 1. total length, 2. width, 3. length of distal part, 4. distance from the first pore to the tip of headshield)) and three of postabdomen (Figure $2 b$ (postabdomen: 1. length, 2. length of ventral margin, 3. width of postabdomen)) were measured for the Alona species and the length of the carapace was measured for Chydorus cf. sphaericus (Figure 2c).

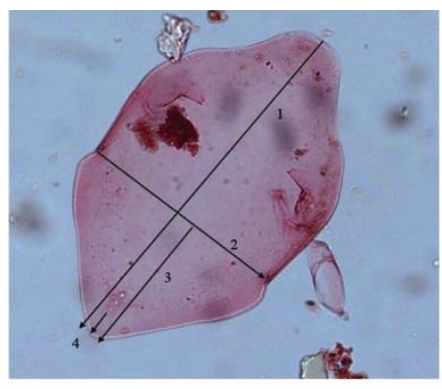

a) Alona sp. headshield

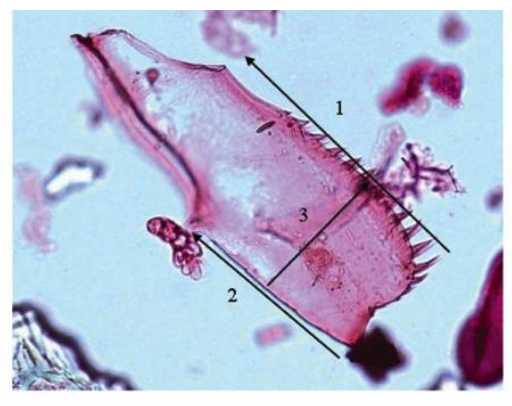

b) Alona sp. postabdomen

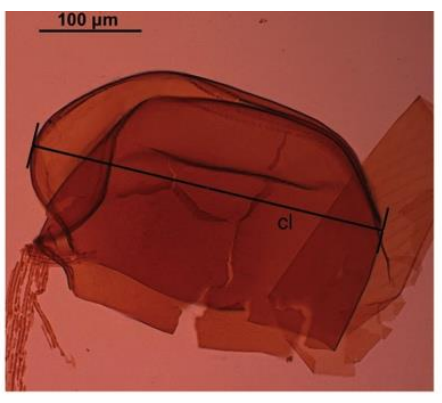

c) Chydorus cf. sphaericus carapace

Figure 2. Measured morphological characteristics: (a) Alona headshields: 1. total length, 2. width, 3. distal length, 4. pore distance of headshield; (b) Alona postabdomens: 1. length, 2. ventral length, 3. width of postabdomen; (c) Chydorus cf. sphaericus carapaces: cl: length of carapace.

\subsection{Data Analyses}

In the case of the fragmented remains of Alona species, linear regression was used to determine the relationship between the length of the headshield and other morphological characters (width, distal length and pore distance), and to establish the relationship between the length of the postabdomen and other morphological characters (width and ventral length). Due to the high proportion of fragmented remains, only those fragments were incorporated into the analysis upon which it was possible to perform at least one measurement.

Prior to linear regression analysis, outliers were determined and omitted from the regressions. Outliers included those with a 2 SD range of residuals of regression (in all, outliers constituted about $10 \%$ of total data). The linear model with the highest $\mathrm{R}^{2}$ values was selected for the calculation of the inferred length, and this inferred length was then used as a substitute for missing data. The distributions of the headshield and postabdomen data were estimated by fitting normal, lognormal and gamma distributions, and from these, the best were selected according to the AIC score (Akaike's An Information Criterion), computed using the maximum-likelihood estimation method and the Kolmogorov-Smirnov goodness of fit test. The analyses were conducted using the 'fitdistrplus' $\mathrm{R}$ package.

Given that the sampling design was unbalanced (cold lakes outnumbered warm lakes), the following strategy was pursued in the grouping of the lakes. First, the question of whether the length of remains from cold environments differed from those from warm environments. At this point, lakes were grouped into "warm" and "cold" sets according to their yearly July mean air temperature. The Finnish and mountain lakes were considered "cold" lakes (range of $\mathrm{T}_{\text {mean July: }}$ $7-17^{\circ} \mathrm{C}$ ), and the others categorized as "warm" lakes (range $\mathrm{T}_{\text {mean July }}: 18-24^{\circ} \mathrm{C}$ ). Next, the cold lakes were examined to see if there comprised a homogeneous group, or whether there are any differences between latitudinal regions, and thus, "cold" lakes were further divided into regions. The Southern Carpathian formed a "Southern cold lakes" group (range of $\mathrm{T}_{\text {mean July: }}$ 8-11 ${ }^{\circ} \mathrm{C}$ ), and the Finnish lakes fell into a group named "Nordic cold lakes". Since the Finnish lakes distributed over a wide 
range of latitude (ca. $10^{\circ} \mathrm{N}$ ), they were further divided into subregions, namely, Southern Finnish (17 lakes, between 60-63 $\mathrm{N}$ latitude), Central Finnish (37 lakes, between $\left.63-66^{\circ} \mathrm{N}\right)$ and Northern Finnish (24 lakes, above $\left.66^{\circ} \mathrm{N}\right)$.

To investigate the effect of depth on the size distribution of remains, the lengths of remains in deep and shallow lakes in the Southern Carpathians were compared. Two lake groups could be identified on the basis of the depth of the lakes. Since thermocline does not usually penetrate below $10 \mathrm{~m}$, on this basis, three lakes could be assigned to the "deep lakes" group, while the others $(n=7)$ became the "shallow lakes" group.

Non-parametric Kruskal-Wallis and Wilcoxon tests were used for between-group comparisons, and the posthoc Nemenyi-test (package PCMCRplus [51]) was employed in the pairwise comparison of lake groups. Finally, a generalized linear model (GLM) was used to identify the effects of latitude and temperature on the length of the remains. All statistical analyses were performed in R [52].

\section{Results}

The various morphological characteristics examined turned out to provide an accurate basis for the estimation of the length of remains (Table A1). For the Alona species, the distal length of headshields and width of the postabdomen best corresponded to total length, and therefore these were used to infer total length for fragmentary remains (Figures A1 and A2).

The lengths of the headshield and postabdomen of $A$. affinis were significantly greater in cold regions than in warm ones (Kruskall-Wallis test: $\chi^{2}=43.254, \mathrm{df}=1, p$-value $<0.05$ ), but the remains of A. quadrangularis displayed a slightly different pattern (Figure 3). The average length of the headshield of $A$. quadrangularis was also significantly greater in cold regions (Kruskall-Wallis test: $\chi^{2}=12.134$, $\mathrm{df}=1, p$-value $=0.05)$, but its postabdomen length did not differ between the climate regions (Figure 3 ). The mean length of the carapace of $C$. cf. sphaericus was also greater in cold regions (Kruskall-Wallis test: $\chi^{2}=7.5481, \mathrm{df}=1, p$-value $<0.05$; Figure 3).

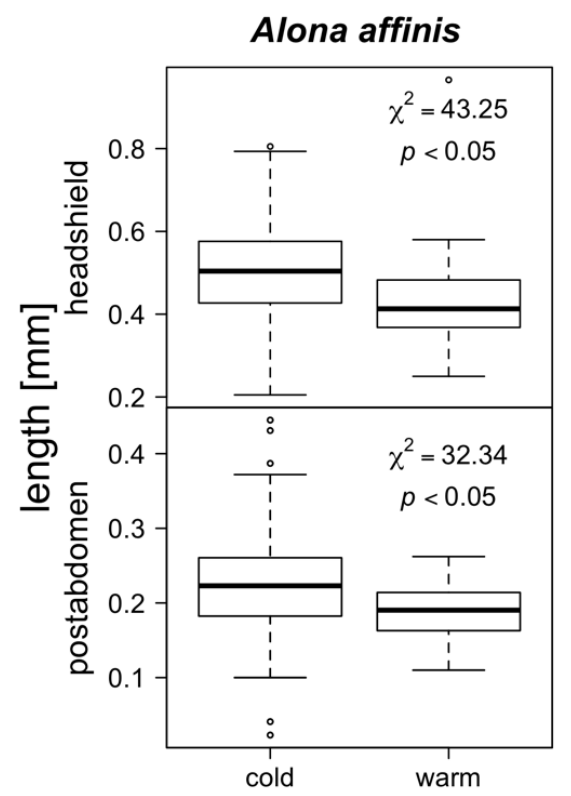

Alona quadrangularis

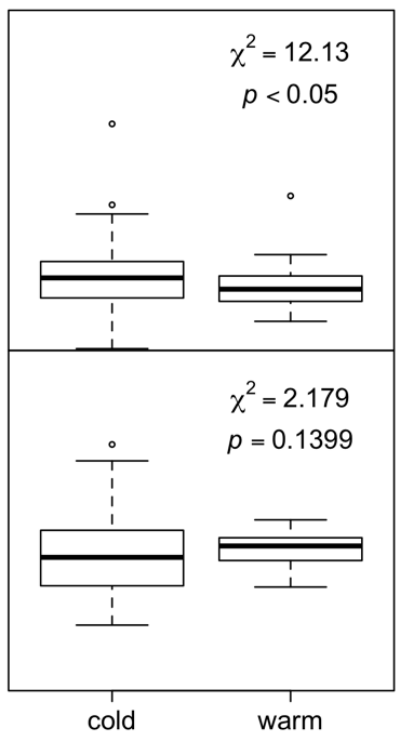

\section{Chydorus sphaericus}

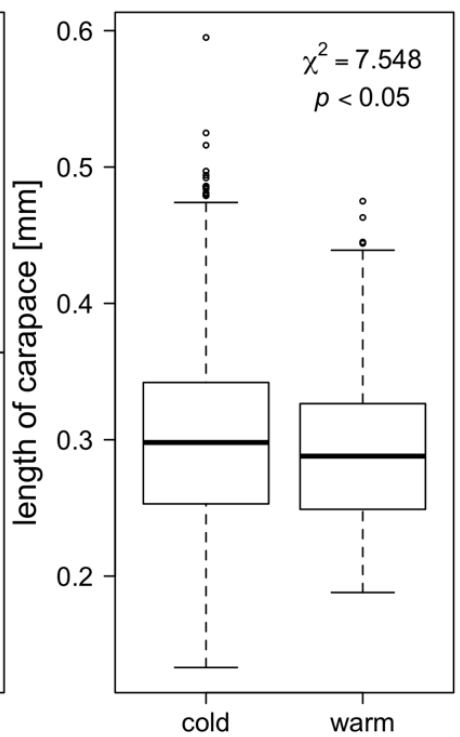

Figure 3. Differences in length of headshields and postabdomens of the Alona species and carapaces of Chydorus sphaericus by temperature regions.

It was the Nordic remains that determined this pattern, since it was in Finland that the headshields of Alona remains and postabdomens of $A$. affinis were the largest (headshields: Kruskall-Wallis test: $\chi^{2}=182.18, \mathrm{df}=2, p$-value $<0.05$; postabdomens: Kruskall-Wallis test: $\chi^{2}=75.903, \mathrm{df}=4$, $p$-value $=1.284 \times 10^{-15} ;$ Figure A3). Interestingly, the lengths of the postabdominal remains of 
A. quadrangularis in the Nordic populations were not distinguishable from those in the warmer regions, and the smallest postambdomens were found in Carpathian lakes (Kruskal-Wallis test: $\chi^{2}=73.398$, $\mathrm{df}=2, p$-value $<0.05)$. The largest Chydorus sphaericus carapaces were found in the Carpathian mountain lakes (Kruskall-Wallis test: $\chi^{2}=26.826, \mathrm{df}=2, p$-value $<0.05$ ).

The next task was to check how the climatic gradient of Finland affected size distribution of the remains, and therefore the Finnish lakes were grouped into three subregions. The size of remains from the Finnish subregions was very similar (Figure A4), with the exception of Chydorus carapaces, which were smallest in the Southern Finnish lakes (Figure A4). The size distribution of sedimental remains between subregions reflects a latitudinal effect, and an increasing trend can be seen in the mean size of remains towards higher latitudes (Figure A4).

The size-frequency distribution of the remains of all species followed lognormal and normal distributions (Appendix A: Figure A2), and the lognormal distribution also applied to the headshield of $A$. affinis, and postabdomen of $A$. quadrangularis, the headshield of $A$. quadrangularis and carapace of $C$. sphaericus displayed a normal distribution These distributions were selected on the basis of the smallest AIC scores (Appendix A: Table A2). Latitude-size (L-S) GLM models revealed an increasing trend in the size of all remains, while temperature-size models (T-S) showed changes in the opposite direction in the length of Alona remains (Figures 4-6, Appendix A: Table A3). The body length of Chydorus sphaericus decreased with increasing temperature (Figure 6, Appendix A: Table A3). Since remains were generally smaller in lakes of the Southern Carpathians than in Finland in spite of the latter's cooler environment, the issue of how the performance of GLM models might change if Southern mountain lakes were excluded from the models was put to the test (Table A3). The L-S models of Alona remains displayed a significant positive relationship with latitude, and this did not change significantly when data from the Carpathian lakes were left out of the models. In contrast, the T-S model of length of all Alona remains showed a positive relationship with temperature when all Carpathian lakes were omitted from the model. The L-S model of C. spharicus did not correspond to temperature, but did display increasingly better performance when the Carpathian lakes were omitted. The T-S model of carapace data also worked well, displaying an inverse correlation with temperature.

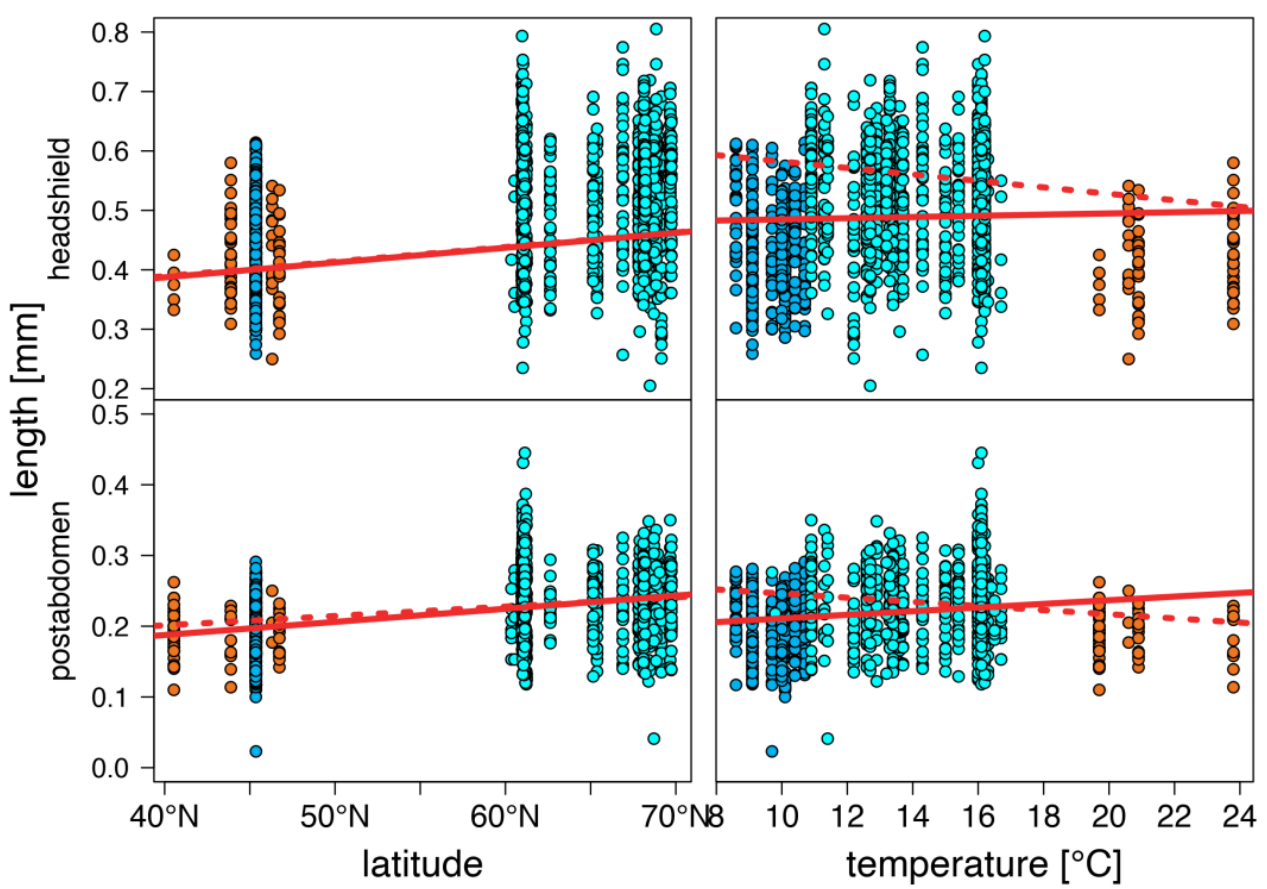

Figure 4. Relationship between latitude (left panel), temperature (right panel) and length of headshield and postabdomen of Alona affinis ( $\odot$ warm lakes, o Southern mountain lakes, o Finnish lakes, solid line: all-lake model, dashed line: omit-SM model; Table A3). 


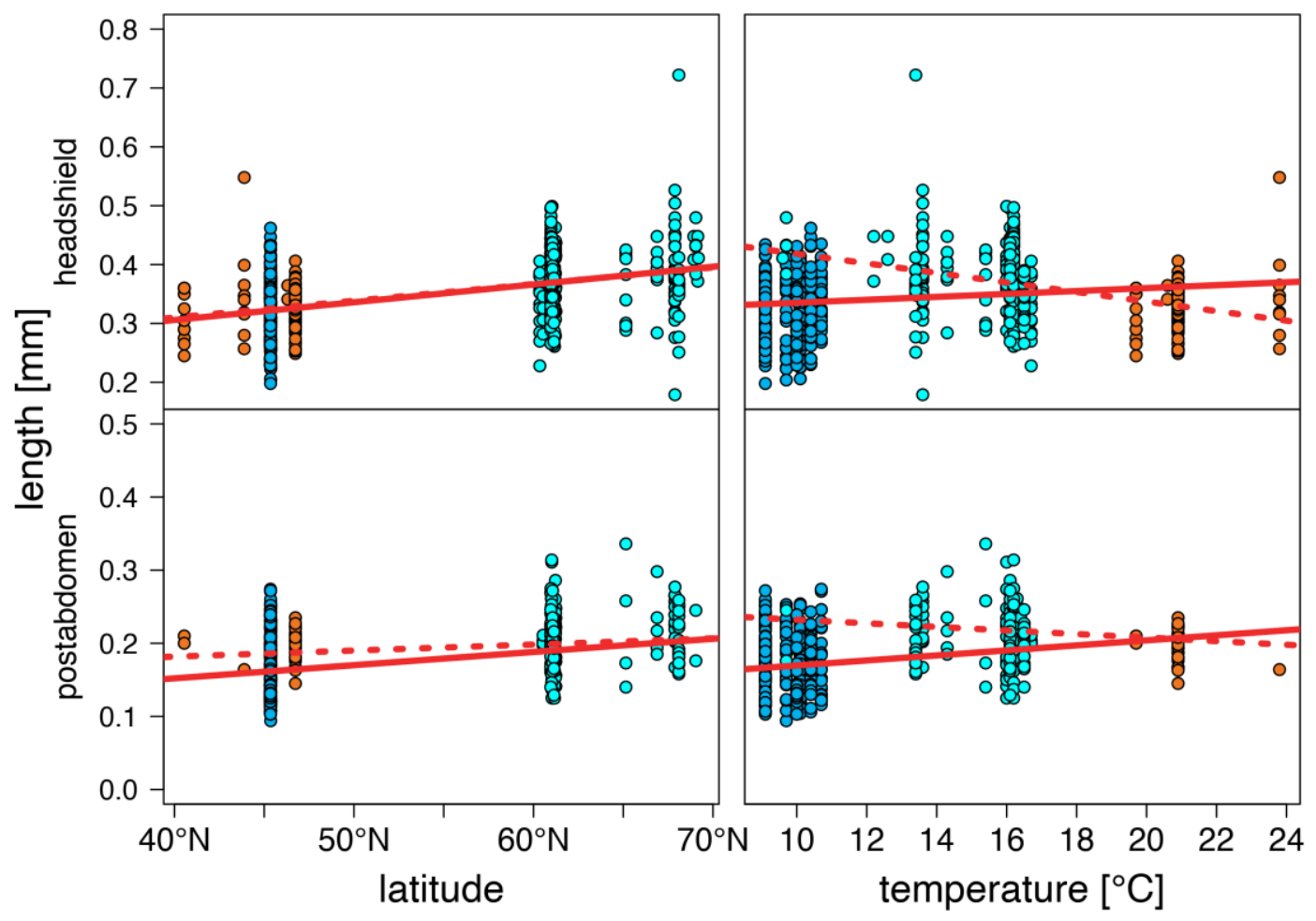

Figure 5. Relationship between latitude (left panel), temperature (right panel) and length of headshield and postabdomen of Alona quadrangularis (O warm lakes, o Southern mountain lakes, o Finnish lakes, solid line: all-lake model, dashed line: omit-SM model; Table A3).
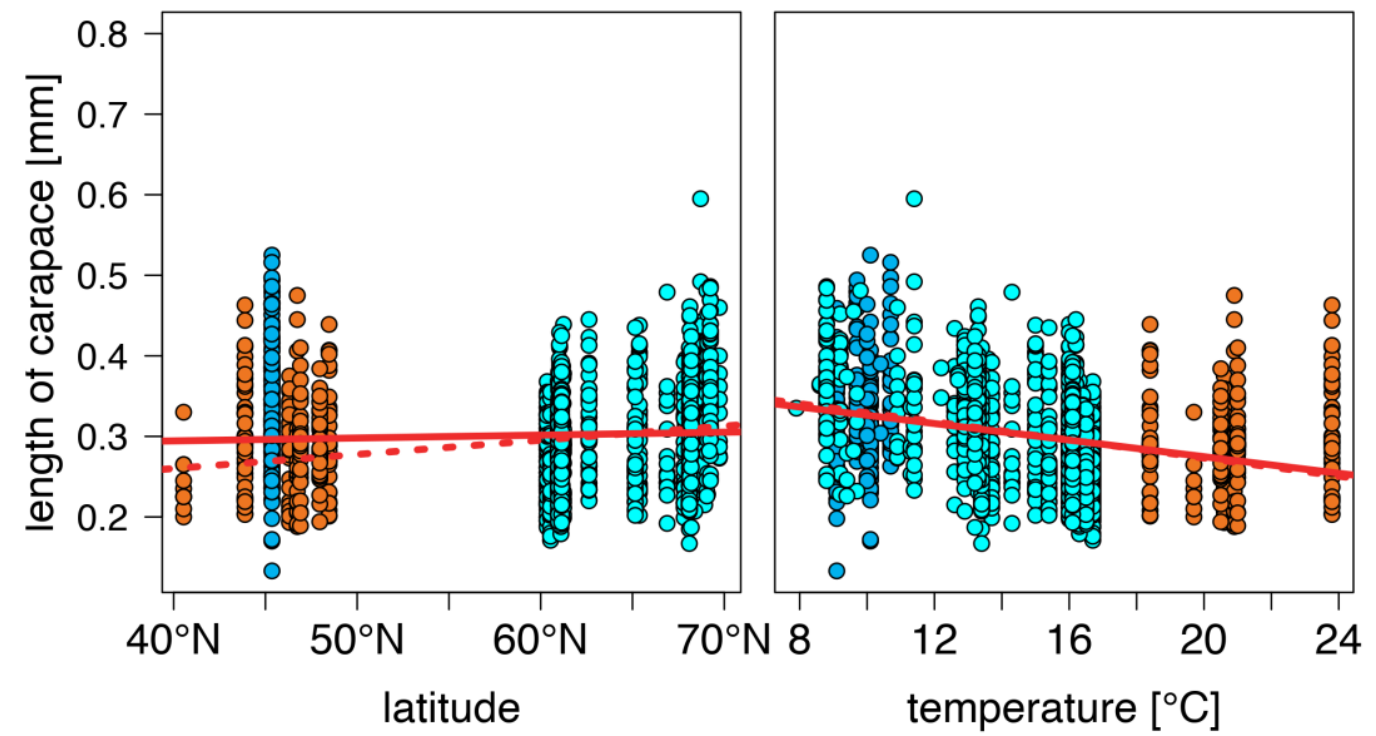

Figure 6. Relationship between latitude (left panel), temperature (right panel) and length of carapace of Chydorus cf. sphaericus ( $\bigcirc$ warm lakes, ○ Southern mountain lakes, o Finnish lakes, solid line: all-lake model, dashed line: omit-SM model; Table A3).

The lengths of the headshields of $A$. affinis were similar in both deep and shallow lakes (Wilcoxon-test: $\mathrm{W}=8724, p=0.29$ ), but the headshields of $A$. quadrangularis were smaller in deep lakes (Wilcoxon-test: $\mathrm{W}=6880, p=0.04$ ). The lengths of the postabdomens of Alona species followed the same pattern as their headshields, also as, the postabdomens of $A$. affinis (Wilcoxon-test: $\mathrm{W}=8682.5$, $p=0.27$ ), while the postabdomens of $A$. quadrangularis were smaller in deep lakes (Wilcoxon-test: 
$\mathrm{W}=6958, p=0.06)$. The carapaces of $C$. cf. sphaericus were larger in deep lakes in contrast to those of Alonas (Wilcoxon-test: $\mathrm{W}=6653, p<0.05$ ).

This comparison was repeated with the Finnish data (eight deep and 38 shallow lakes), and it was found that the lengths of remains did not differ between groups (Wilcoxon-tests: headshields of $A$. affinis: $\mathrm{W}=9943, p=0.44$; postabdomens of A. affinis: $\mathrm{W}=3654.5, p=0.64$; headshields of A. quadrangularis: $\mathrm{W}=314.5, p=0.66$; postabdomens of $A$. quadrangularis: $\mathrm{W}=379, p$-value $=0.87$; carapaces of $C$. cf. sphaericus: $\mathrm{W}=44686, p=0.56$ ).

\section{Discussion}

This is the first study in which the morphological response of littoral cladocerans has been examined in relation to the ambient temperature of the location of their sedimentary remains. Typically, paleolimnological inferences are based on assemblages of cladoceran species, but cladoceran size structure is also sensitive to changes in limnological conditions [53]. Mean cladoceran body size, a community metric, has been used mainly to infer fish and invertebrate predation regimes [54-56], but relationships between body size and climate have also been documented $[5,7,57,58]$.

The comparison of inferred length to measured length reveals that the allometric growth of body parts was not to be observed, and inferred length could, therefore, be used to supplement missing data (Figures A1 and A2).

The analyses revealed that the average length of headshield and carapace is smaller in larger environments, as was expected. This result confirms the temperature-size hypothesis (TSR: [13,59]), and hence, the remains are generally smaller in warm lakes. However, the unexpected result of the analysis was that the length postabdomen of A. quadrangularis in warm lakes did not differ significantly from that of those found in cool environments. This can be explained by the distinctly different shapes of the postabdomen of A. affinis and A. angularis. The causes of these differences are difficult to unravel, but they may be related to habitat preferences and the ecological niche of the Alona species. The large Alona sp. (A. quadrangularis and A. affinis) are adapted to benthic habitats, and A. quadrangularis is specifically considered a mud dweller [60-62], while $A$. affinis prefers dense vegetation [61], but it can be found widely over the littoral zone [36]. Littoral cladocerans have developed many systems to exploit periphyton, including mechanisms of food selection, along with many other particular adaptations $[63,64]$. The postabdomenis is a key morphological feature of these cladocerans, as in the case of $A$. quadrangularis, which uses these parts for locomotion and to clean the food canal and toracopodes [63]. Here, it might be propose that in this, A. quadrangularis displays an evolutionary adaptation to a muddy bottom environment, with its widened carapace posteriorly. It is also possible that allometric body growth, in which the larger postabdomen has an advantage, is an evolutionary strategy for the maximization of niche exploitation. The axe shape (rounded ventral margin) of postabdomen of A. quadrangularis is very like that of other mud dwelling species (Ilyocryptus spp., Leydigia spp.), and thus can be regarded as an adaptation to a muddy environment. Low-oxygen conditions are also a factor to consider when dealing with benthic organisms. According to Van-Damme et al. [65] benthic Aloninae require a large "exopodite pump", which is probably a very specialized feature, along with the postabdomen. These factors together may well explain the differences found in the response of postabdomen length to ambient temperature in comparison with that observed in the case of headshields.

It was found that, in general, larger remains predominated in colder environments, confirming the hypothesized effect of climate on the size of the the distribution of littoral species, while the effect of climate on the size of planktonic species has previously been documented. Manca and Comoli [58] found larger Daphnia headshields coinciding with cold climate events in the late Holocene in the Nepalese Himalayas. In the regions in this study, Korponai et al. [25] found the occurrence of larger ephippia in Daphnia during the Late Glacial than those in the Holocene in the South Carpathians, and Nevalainen et al. [66] also documented that the size of the ephippia of Bosmina and Daphnia were larger during the cold periods of the Late Holocene in a Finnish lake. The physiological advantages 
of larger cladoceran body size in cold climatic conditions are manyfold. In a cold environment, individuals with a larger maturation size have a higher degree of fitness [67]. Fitness, in turn, depends on food supply, and therefore increased filtering efficiency increases individual fitness, and this has advantages in cases of low food concentration. The filtering setae number (FSN) is constant for the whole life-span of individuals [68], and FSN increases with body size [69]. Therefore larger individuals are efficient filterers of phytoplankton, due to their larger filtering screen, thus the large-bodied cladocerans are more effective grazers, since they have a lower threshold of food [70]. It seems reasonable to assume that a larger filtering screen is probably an adaptive response [71,72] in local benthic cladocerans as well. In addition, larger females produce larger ephippia and these ephippia have a larger hatching probability. Larger eggs then have the benefit of resulting in larger neonates, which in turn yield larger adults [73].

The clear increasing trend observed in the size of all remains with latitude is in agreement with the size-efficiency hypothesis, since latitudinal changes may describe a general pattern of body size changes articulated in both Bergmann's [74] and Atkinson's rules [13]. Generally, the T-S relationship would correspond to the L-S, and in aquatic species, this can be explained in terms of the oxygen supply, since warm water contains less oxygen $[59,75,76]$. Large body size has no advantage in a warm environment, while such species exhibit a low surface-area to body-mass ratio. Due to the increased oxygen demand of these species, they will suffer from oxygen depletion, and consequently, must sustain their growth in order to achieve a higher surface-area to body-mass ratio to increase oxygen uptake $[77,78]$. Therefore, smaller species are found in warm environments $[76,79,80]$.

The strength of the associations between the T-S and L-S gradients can vary, depending on the particular species. Body size can be influenced by not only ambient temperature, but also season length, productivity, mortality and somatic plasticity, or by some combination of these [76]. Havens et al. [5] found that the body size of planktonic cyclopoid copepods had a strong relationship with temperature, while in the case of planktonic cladocerans this was weak and with calanoids it was insignificant in their comprehensive study. The discrepancy between the latitude-size (L-S) and temperature-size (T-S) models can be explained by the distribution of littoral species due to depth, hence in this research the question of whether the species would display any response to water depth was investigated. In deep and stratified lakes, the water temperature is lower, and its seasonal changes are smooth in the hypolimnion [81,82]. Therefore, populations of benthic species, which inhabit the region below the thermocline, live in a stable thermal environment. The thermal differences in the sediment surface between deep and shallow lakes may be reflected in the size of remains. Although the data in this study were unbalanced, since there were more shallow lakes in the data set than deep ones, the results show that thermal differences in littoral and profundal areas may not have a significant effect on the size distributions of the remains due to the accumulation of remains in the deepest areas. In his intra-lake studies, Luoto $[83,84]$ found that the distribution of chironomid remains is closely related to water depth and suggested that the fact that fossils accumulate near each species' habitat may cause some bias in single-core paleolimnological studies.

A species-dependent response to temperature gradients was also observed. Direct T-S relationships were insignificant in the case of Alona species, due to the small size of the remains from the Southern Carpathians, but were strong and significant in the case of $C$. cf. sphaericus..

Remains of Alona species in the lakes of South Carpathians were generally smaller than those from Finland (Figure A3). Since these Alona species are larger than C. cf. sphaericus, it was, therefore, reasonable to assume that in this case, the decrease in body size was the result of fish predation. Havens et al. (2015) demonstrated the effect of fish predation on cladoceran body size in the lakes of Greenland, with a fivefold increase in body size in the fish-free lakes than those with fish. The lengths of Alona remains from a subset of Finnish lakes inhabited by fish [85] were therefore compared with those from Southern Carpathian lakes. For the purposes of analysis, all southern mountain lakes were considered to be populated by fish, since a few lakes were naturally inhabited by trout (Salmo trutta), but almost all mountain lakes were stocked with trout between 1961 and 1977 [86]. Moreover, schools of common 
minnows (Phoxinus phoxinus) were seen from the shore of Carpathian lakes during the field sampling. Minnows are found in a variety of microhabitats in the littoral, but seem to prefer stony, shallow sites [87] as do most chydorids. Although minnow is the main prey of trout, the diets of young trout and minnow overlap, that is, they utilize the same food resources, and therefore both species have an effect on cladocerans $[36,88,89]$. Predation patterns in the littoral form a complex picture. Since both predatory fish and invertebrates utilize this zone, and fish also feed on invertebrate predators [31], the density of fish populations influences invertebrate predation pressure [29,31]. Both types of predation affect the structure of the littoral cladoceran community. Adamczuk [36] showed that fish prefer larger chydorids, and thus larger species tend to occupy dense vegetation. Basińska [38] found that Chydorus reached a large size in helophyte beds, a fact explicable in the light of the influence of macroinvertebrate predators. The scarce or absent macrophytes in the littoral zone of Carpathian lakes did not supply shelter for cladocerans, and thus predation pressure from fish explicitly affects the larger Alona species than the smaller C. sphaericus, causing a decrease in size in the Alona spp. population.

In arctic and subarctic lakes in Finland, zooplankton density is higher in lakes containing fish, and this is mainly due to the higher density of small-sized cladocerans and cyclopoids that escape grazing from high-latitude fish species. Moreover, large-sized cladocerans are found in lower densities in fish-free lakes $[90,91]$. Since fish prefer larger cladocerans, fish predation shifts the size spectrum of cladocerans towards the smaller range, and leads to a conclusion that fish predation enhances the effect of temperature on body size. Lakes in mid and southern Finland are exposed to nutrient enrichment [92,93], so in these lakes macrophyte density and species diversity increase. The macrophyte belt can provide shelter against predators for macroinvertebrates, and macroinvertebrate predation increases the body size of littoral cladocerans [34]. These top-down effects may well, therefore, explain the large headshield of Alonas in Southern Finnish lakes.

Alona spp. remains were smaller in the lakes of the Southern Carpathians (Figure A3) than in fish-populated lakes in Finland, and in this case, the former was also fish-populated. Consequently, the incidence of smaller sized Alona remains could not be explained by the impact of fish. Manca and Comoli [58] studied fish-free mountain lakes in the Himalayas, where the number of moults and Daphnia body size depended on summer temperatures and on the duration of the ice-free period. They found that in cold years, when the productive season was short, the number of moults were low, and the range of body sizes was reduced. The range of size remains highly dependent on the proportion of juveniles, and thus in cases where the cladocera population finds suitable environmental conditions, a high number of juveniles will develop, causing a high degree of variance in the data. The weak correlation observed between the length of remains and ambient temperature was due to high variances. Complete T-S models of Alonas appear to contradict Atkinson's rule; however, if the Carpathian lakes are excluded, the models changed, decreasing to the point of a significant degree of agreement with the temperature-size hypothesis. We may, therefore, assume that the smaller size of the Southern mountain populations of Alona species is explained by factors other than temperature, factors which also affect size distribution. What is more, the smaller size is the result of the adaptation of a local population with a distinct genetic background.

Belyaeva and Taylor [94] revealed that C. sphaericus represents a species complex with a Holarctic distribution. They describe two European clades (A1 and A2), which look very similar, and hence cannot be distinguished through the use of carapace morphology, as the identifiable substantial difference is in gamogenetic individuals. Both clades (A1 and A2) occur in the Nordic populations of Chydorus sphaericus, but the A2 clade probably dominates at higher latitudes [94]. This A2 clade is similar to C. biovatus as described in Salmon Lake, Montana, USA [95]. They made the reasonable demand that, henceforth, further studies should be required to clarify the taxonomic status and the position of this taxon within the Chydorus sphaericus complex. Van Damme and Eggermont [96] also found that the average body size of high mountain populations of $C$. cf. sphaericus in the Rwenzori Mountains in the Democratic Republic of the Congo were larger than the Palearctic populations. 
They suggested that the difference in size might be indicative of some degree of local adaptation and speciation (Löffler island).

In conclusion, this study reveals that littoral cladocerans exhibit a body-size response to climate over a wide geographical range across Europe. The length of headshields and carapaces may be regarded as a realistic proxy for climatic changes. Therefore, long-term changes in size distribution of their remains may provide information on climate oscillations in paleolimnological records. The analyses presented here also point to the fact that a regional heterogeneity in body size distribution which can obscure these relations may be expected to occur among populations. It may consequently be assumed that the genetic heterogeneity of species is responsible for size differences in littoral cladoceran populations.

Author Contributions: J.L.K., C.K., C.L.-B., I.G., M.K., L.N., T.P.L., K.S.-K., J.W., I.U. contributed to the fieldwork, J.L.K., C.K., C.L.-B. and I.G. carried out the measurements and J.L.K. performed the statistical analysis. J.L.K., C.K., C.L.-B., I.G., L.F., A.K., M.K., L.N., T.P.L., K.S.-K., E.K.M., J.W., I.U., E.V. and K.B. contributed to the writing of the manuscript. All authors have read and agreed to the published version of the manuscript.

Funding: A scholarship to J.L.K. was funded by the Balassi Institute-Campus Hungary (Project number:B2/4H/13307). The research was supported by the GINOP-2.3.2-15-2016-00019 and National Research, Development and Innovation Office-NKFIH, 120595, 119208 grants of the Ministry of Innovation and Technology in Hungary. The research was also financed by the Higher Education Institutional Excellence Programme (NKFIH-1150-6/2019) of the Ministry of Human Capacities in Hungary, within the framework of the 4. thematic program of the University of Debrecen.

Acknowledgments: J.L.K. would like to give specials thanks to Tapani Rämö for the support of the Department of Geosciences and Geography of the University of Helsinki. A special thank you goes to the support of the Retezat National Park (Nr. 423/27.06.2011, Nr. 516/25.06.2012, 593/25.07.2012 and Nr. 629/27.07.2015).

Conflicts of Interest: The authors declare no conflict of interest. The funders had no role in the design of the study, in the collection, analyses, or interpretation of data, in the writing of the manuscript, or in the decision to publish the results.

\section{Appendix A}

Table A1. Coefficients of linear regressions $(y=a x+b)$ of headshields and postabdomen measurements of Alona affinis and A. quadrangularis.

\begin{tabular}{cccccc}
\hline \multicolumn{7}{c}{ Alona affinis } \\
\hline headshield & $\mathrm{a}$ & $\mathrm{b}$ & $t$-value & $\mathrm{R}^{2}$ & $p$ \\
\hline width & 0.5465 & -0.00881 & 56.7427 & 0.8712 & $<0.05$ \\
distal length & 0.4232 & -0.00074 & 120.2307 & 0.9527 & $<0.05$ \\
pore distance & 0.0878 & -0.02046 & 46.6102 & 0.8165 & $<0.05$ \\
\hline postabdomen & $\mathrm{a}$ & $\mathrm{b}$ & $t$-value & $\mathrm{R}^{2}$ & $p$ \\
\hline width & 0.4177 & 0.01548 & 32.5566 & 0.9013 & $<0.05$ \\
distal length & 0.5216 & 0.0205 & 20.2443 & 0.785 & $<0.05$ \\
\hline \multicolumn{7}{c}{ Alona quadrangularis } \\
\hline headshield & $\mathrm{a}$ & $\mathrm{b}$ & $t$-value & $\mathrm{R}^{2}$ & $p$ \\
\hline width & 0.5446 & 0.01065 & 26.8956 & 0.697 & $<0.05$ \\
distal length & 0.4074 & 0.00051 & 61.1244 & 0.9125 & $<0.05$ \\
pore distance & 0.151 & -0.0276 & 44.3056 & 0.8639 & $<0.05$ \\
\hline postabdomen & $\mathrm{a}$ & $\mathrm{b}$ & $t$-value & $\mathrm{R}^{2}$ & $p$ \\
\hline width & 0.4192 & 0.01665 & 27.6451 & 0.9526 & $<0.05$ \\
ventral length & 0.5192 & 0.02206 & 10.3076 & 0.7296 & $<0.05$ \\
\hline
\end{tabular}




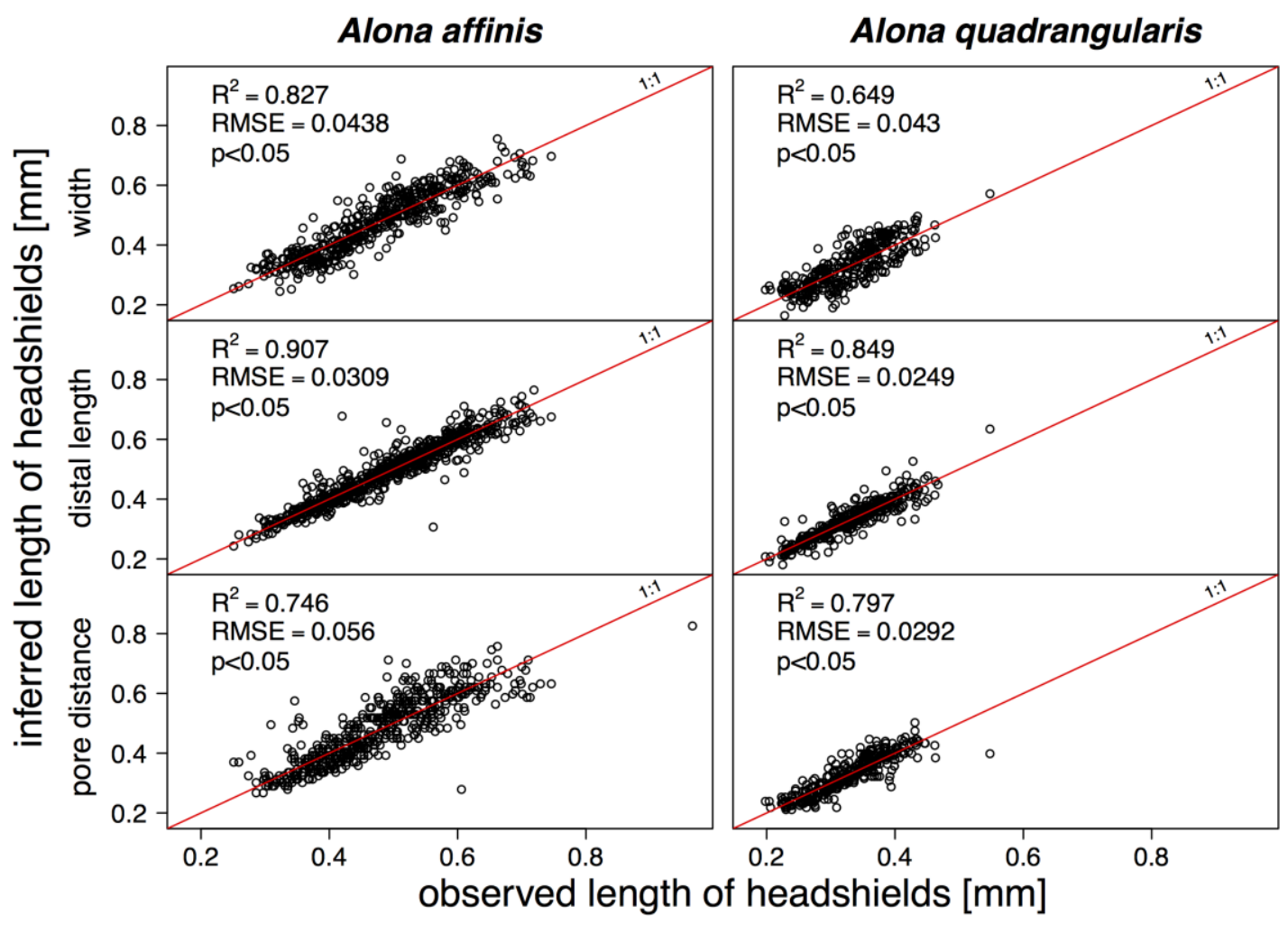

Figure A1. Inferred headshield length of Alona species.

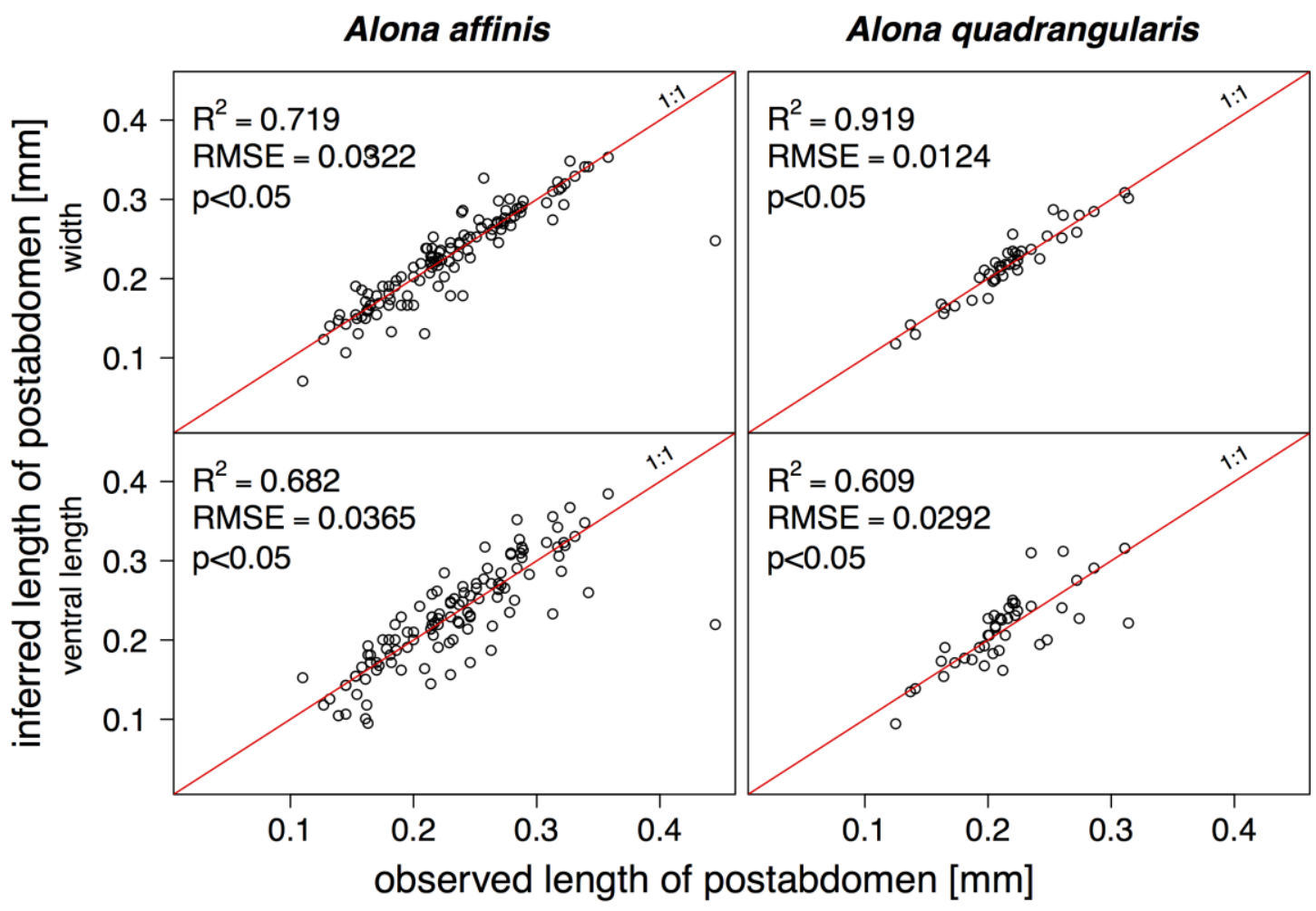

Figure A2. Inferred postabdomen length of Alona species. 


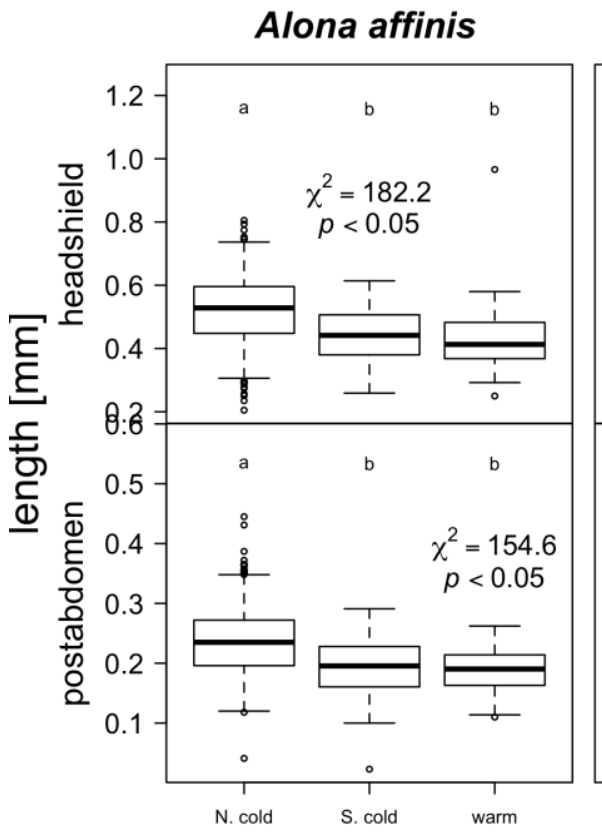

Alona quadrangularis

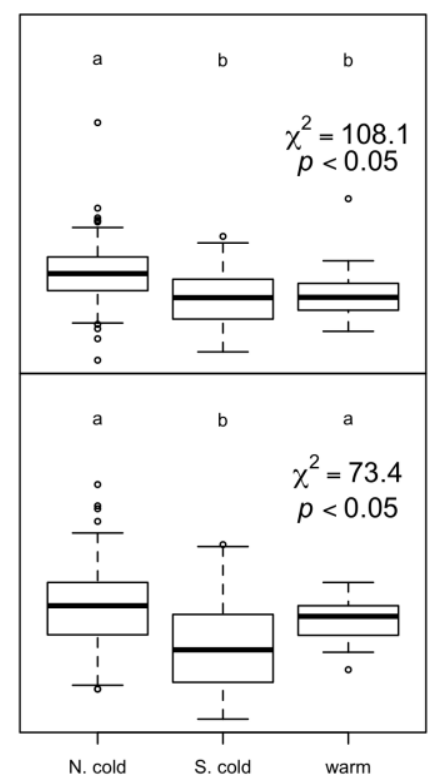

Chydorus sphaericus

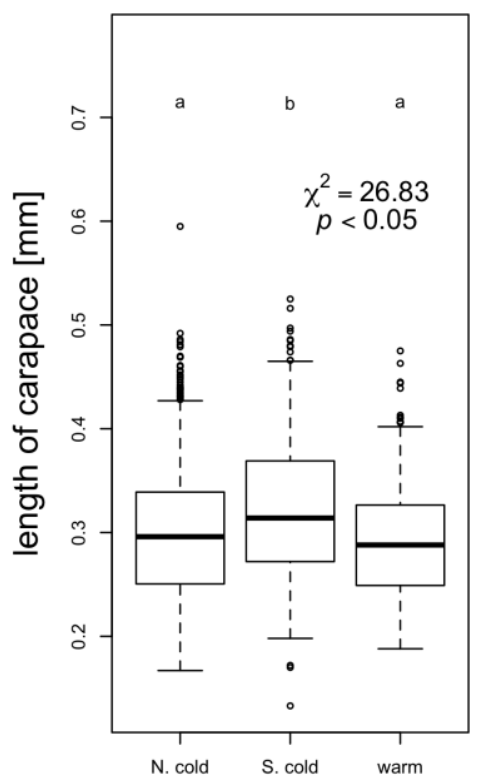

Figure A3. Regional differences in length of headshields, postabdomen and carapaces (Alona affinis, A. quadrangularis and Chydorus sphaericus, N.cold: Nordic cold lakes, S.cold: high mountain lakes, warm: lakes in the south of Europe; groups with the same letters are not distinguishable, whereas groups with different letters differ significantly).
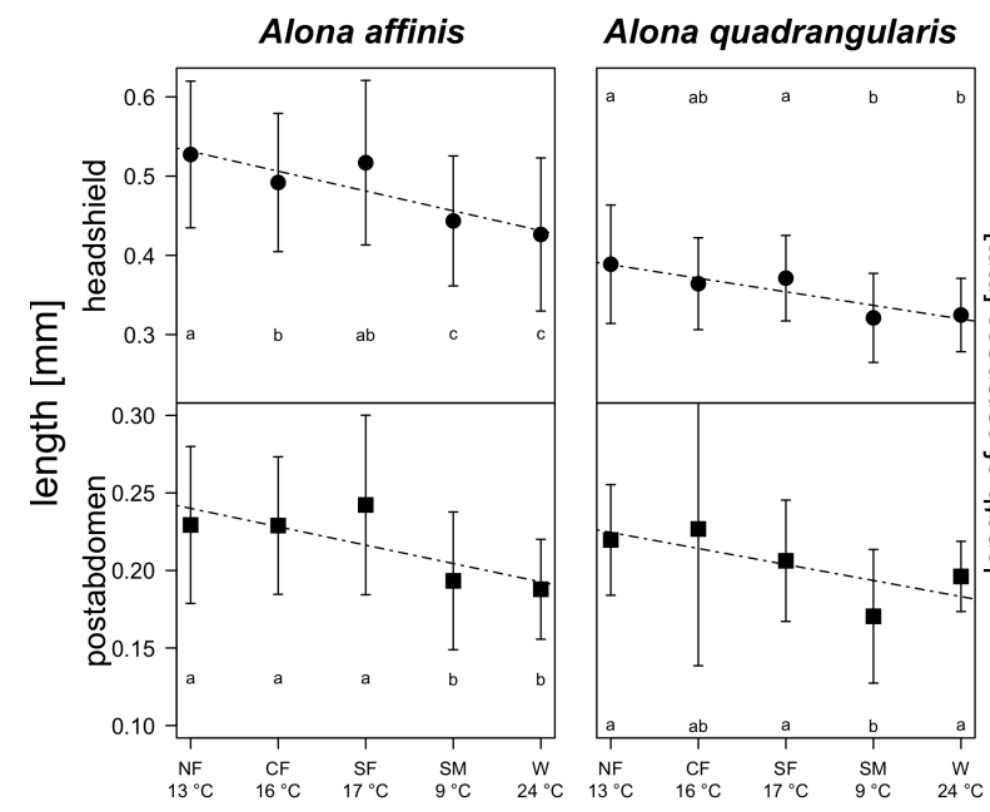

\section{Chydorus sphaericus}

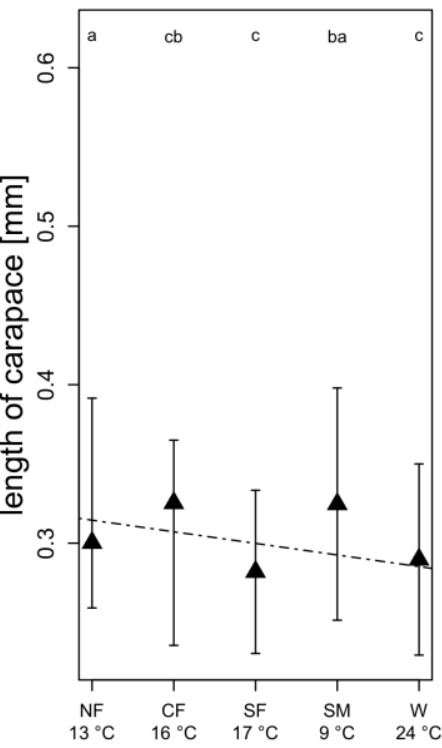

Figure A4. Distribution of mean lengths of headshields $(\bullet)$, postabdomens $(\boldsymbol{\square})$ of Alona species and carapaces ( $\mathbf{\Lambda}$ ) of Chydorus spharicus among subregions (NF: North of Finland, CF: Central of Finland, SF: South of Finland, SM: Southern mountain lakes, W: warm lakes; groups with the same letters are not distinguishable, whereas groups with different letters differ significantly). 

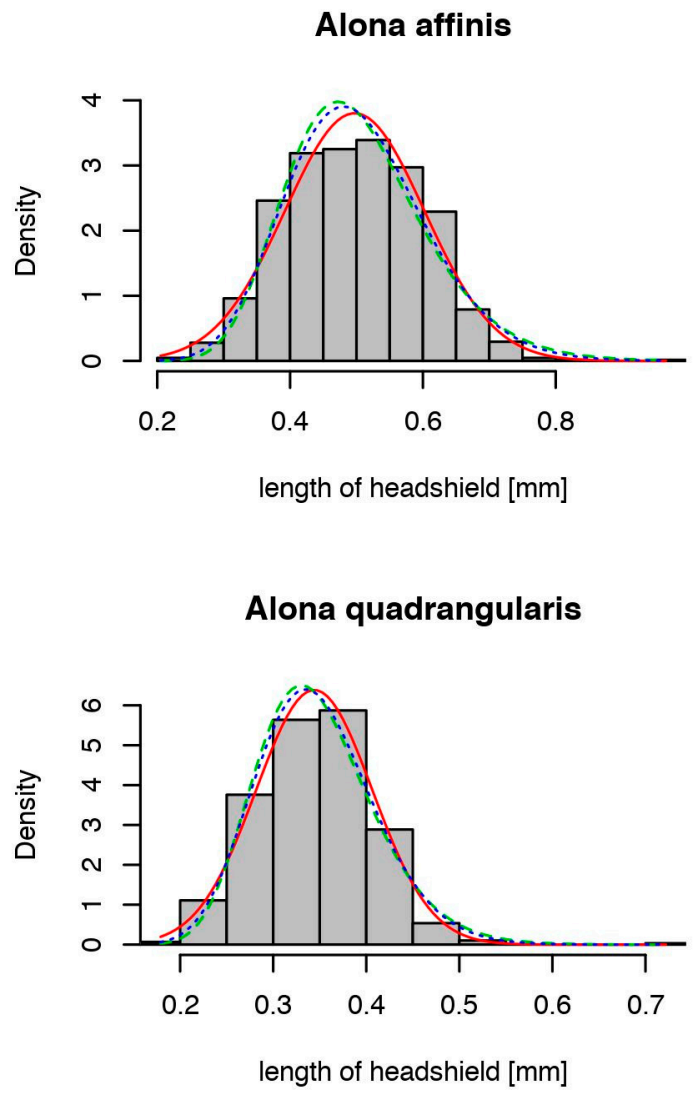

Chydorus cf. sphaericus

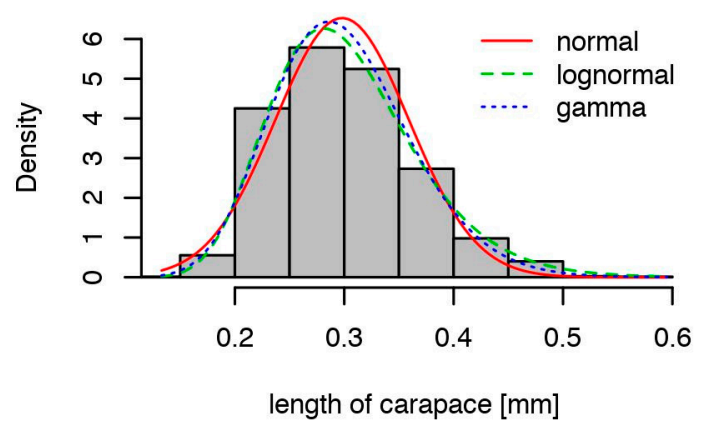

Alona affinis

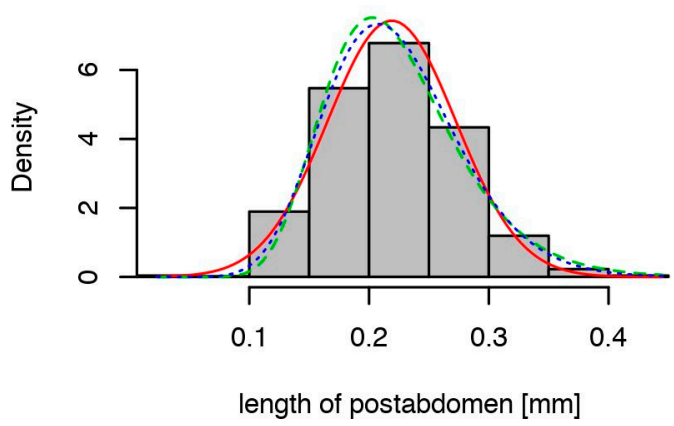

Alona quadrangularis

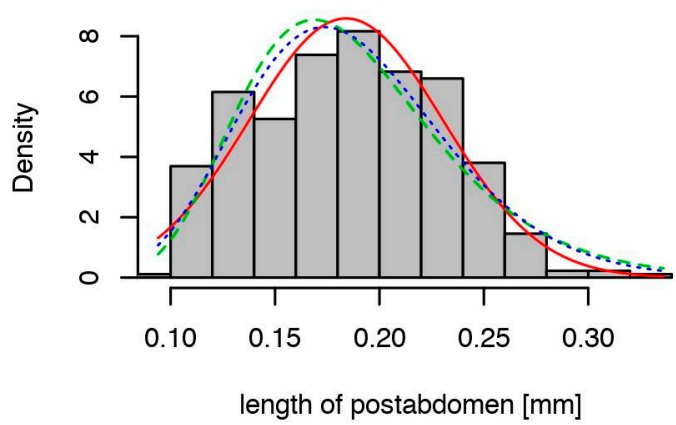

Figure A5. Size-frequency distribution of cladocera remains.

Table A2. Akaike's information criteria for L-S and T-S models. Smallest values are marked in bold.

\begin{tabular}{llll}
\hline \multicolumn{4}{c}{ Akaike's An Information Criterion (AIC) } \\
& Normal & Lognormal & Gamma \\
\hline Alona affinis & & & \\
\hline headshield & $-\mathbf{2 2 6 7}$ & -2230 & -2261 \\
postabdomen & $-\mathbf{3 1 5 0}$ & -3072 & -3137 \\
A. quadrangularis & & & \\
\hline headshield & -1609 & -1613 & $\mathbf{- 1 6 2 0}$ \\
postabdomen & -1497 & -1489 & $\mathbf{- 1 4 9 7}$ \\
Chydorus sphaericus & & & \\
\hline \multicolumn{1}{c}{ carapace } & -4120 & $-\mathbf{4 2 1 1}$ & -4208 \\
\hline
\end{tabular}


Table A3. Coefficients of the generalized linear model of the relationship between latitude and length of remains (all lake model: the model contains all lake; omit-model: Southern Carpathian lakes left out the model).

\begin{tabular}{|c|c|c|c|c|c|c|c|}
\hline Model & & Parameter & Estimate & Std. Error & $t$ Value & $p$-Value & AIC \\
\hline \multicolumn{8}{|l|}{ Alona affinis } \\
\hline \multirow[t]{8}{*}{ headsield } & \multirow[t]{2}{*}{ all lake model } & Intercept & 0.288 & 0.011 & 23.178 & $<0.001$ & -3491 \\
\hline & & latitude & 0.002 & 0.000 & 13.87 & $<0.001$ & \\
\hline & \multirow{2}{*}{ omit-model } & Intercept & 0.291 & 0.021 & 12.075 & $<0.001$ & -2628 \\
\hline & & latitude & 0.002 & 0.000 & 7.473 & $<0.001$ & \\
\hline & \multirow{2}{*}{ all lake model } & Intercept & 0.475 & 0.008 & 47.63 & $<0.001$ & -3314 \\
\hline & & $\mathrm{T}_{\mathrm{Jul}}$ & 0.001 & 0.001 & 1.692 & 0.091 & \\
\hline & \multirow[t]{2}{*}{ omit-model } & Intercept & 0.637 & 0.011 & 43.813 & $<0.001$ & -2624 \\
\hline & & $\mathrm{T}_{\text {Jul }}$ & -0.005 & 0.001 & -7.19 & $<0.001$ & \\
\hline \multirow[t]{8}{*}{ postabdomen } & \multirow[t]{2}{*}{ all lake model } & Intercept & 0.120 & 0.009 & 12.202 & $<0.001$ & -3277 \\
\hline & & latitude & 0.002 & 0.000 & 11.673 & $<0.001$ & \\
\hline & \multirow[t]{2}{*}{ omit-model } & Intercept & 0.160 & 0.017 & 8.891 & $<0.001$ & -2280 \\
\hline & & latitude & 0.001 & 0.000 & 4.985 & $<0.001$ & \\
\hline & \multirow[t]{2}{*}{ all lake model } & Intercept & 0.475 & 0.008 & 47.63 & $<0.001$ & -3314 \\
\hline & & $\mathrm{T}_{\text {Jul }}$ & 0.001 & 0.001 & 1.692 & 0.091 & \\
\hline & \multirow[t]{2}{*}{ omit-model } & Intercept & 0.637 & 0.011 & 43.813 & $<0.001$ & -2624 \\
\hline & & $\mathrm{T}_{\mathrm{Jul}}$ & -0.005 & 0.001 & -7.19 & $<0.001$ & \\
\hline \multicolumn{8}{|c|}{ Alona quadrangularis } \\
\hline \multirow[t]{8}{*}{ headsield } & \multirow[t]{2}{*}{ all lake model } & Intercept & 0.185 & 0.014 & 13.325 & $<0.001$ & -1729 \\
\hline & & latitude & 0.003 & 0.000 & 11.593 & $<0.001$ & \\
\hline & \multirow[t]{2}{*}{ omit-model } & Intercept & 0.196 & 0.024 & 8.342 & $<0.001$ & -940 \\
\hline & & latitude & 0.003 & 0.000 & 7.154 & $<0.001$ & \\
\hline & \multirow[t]{2}{*}{ all lake model } & Intercept & 0.310 & 0.009 & 34.854 & $<0.001$ & -1623 \\
\hline & & $\mathrm{T}_{\mathrm{Jul}}$ & 0.002 & 0.001 & 3.955 & $<0.001$ & \\
\hline & \multirow[t]{2}{*}{ omit-model } & Intercept & 0.499 & 0.019 & 25.684 & $<0.001$ & -939 \\
\hline & & $\mathrm{T}_{\text {Jul }}$ & -0.008 & 0.001 & -7.087 & $<0.001$ & \\
\hline \multirow[t]{8}{*}{ postabdomen } & \multirow[t]{2}{*}{ all lake model } & Intercept & 0.080 & 0.010 & 7.585 & $<0.001$ & -1728 \\
\hline & & latitude & 0.002 & 0.000 & 9.258 & $<0.001$ & \\
\hline & \multirow[t]{2}{*}{ omit-model } & Intercept & 0.148 & 0.022 & 6.493 & $<0.001$ & -722 \\
\hline & & latitude & 0.001 & 0.000 & 2.366 & 0.019 & \\
\hline & \multirow[t]{2}{*}{ all lake model } & Intercept & 0.135 & 0.006 & 20.307 & $<0.001$ & -1697 \\
\hline & & $\mathrm{T}_{\text {Jul }}$ & 0.003 & 0.000 & 7.076 & $<0.001$ & \\
\hline & \multirow[t]{2}{*}{ omit-model } & Intercept & 0.257 & 0.017 & 13.76 & $<0.001$ & -722 \\
\hline & & $\mathrm{T}_{\mathrm{Jul}}$ & -0.002 & 0.001 & -2.423 & 0.016 & \\
\hline \multicolumn{8}{|c|}{ Chydorus spharicus } \\
\hline carapace & all lake model & Intercept & 0.280 & 0.011 & 24.852 & $<0.001$ & -4132 \\
\hline & & latitude & 0.000 & 0.000 & 1.909 & 0.056 & \\
\hline & omit-model & Intercept & 0.190 & 0.014 & 13.313 & $<0.001$ & -3727 \\
\hline & & latitude & 0.002 & 0.000 & 7.617 & $<0.001$ & \\
\hline & all lake model & Intercept & 0.378 & 0.007 & 55.581 & $<0.001$ & -4256 \\
\hline & & $\mathrm{T}_{\mathrm{Jul}}$ & -0.005 & 0.000 & -11.543 & $<0.001$ & \\
\hline & omit-model & Intercept & 0.386 & 0.008 & 46.03 & $<0.001$ & -3780 \\
\hline & & $\mathrm{T}_{\mathrm{Jul}}$ & -0.006 & 0.001 & -10.69 & 0.000 & \\
\hline
\end{tabular}

\section{References}

1. Litchman, E.; Ohman, M.D.; Kiørboe, T. Trait-Based Approaches to Zooplankton Communities. J. Plankton Res. 2013, 35, 473-484. [CrossRef]

2. Carpenter, S.R.; Kitchell, J.F. Consumer Control of Lake Productivity. BioScience 1988, 38, 764. [CrossRef]

3. Kerfoot, W.C. Egg-Size Cycle of a Cladoceran. Ecology 1974, 55, 1259-1270. [CrossRef] 
4. Razak, S.A.; Saisho, T. Seasonal Variations in Egg Size, Brood Size and Body Length of Bosmina Longirostris (Crustacea: Cladocera) from Lake Ikeda, Japan. Malays. J. Sci. 2004, 23, 121-135.

5. Havens, K.E.; Pinto-Coelho, R.M.; Beklioğlu, M.; Christoffersen, K.S.; Jeppesen, E.; Lauridsen, T.L.; Mazumder, A.; Méthot, G.; Alloul, B.P.; Tavşanoğlu, U.N.; et al. Temperature Effects on Body Size of Freshwater Crustacean Zooplankton from Greenland to the Tropics. Hydrobiologia 2015, 743, 27-35. [CrossRef]

6. Vijverberg, J.; Richter, A.F. Population Dynamics and Production of Daphnia Hyalina (Leydig) and Daphnia Cucullata Sars in Tjeukemeer. Hydrobiologia 1982, 9, 235-259. [CrossRef]

7. Moore, M.V.; Folt, C.L.; Stemberger, R.S. Consequences of Elevated Temperatures for Zooplankton Assemblages in Temperate Lakes. Arch. Hydrobiol. 1996, 135, 289-319.

8. Chang, K.-H.; Hanazato, T. Seasonal and Reciprocal Succession and Cyclomorphosis of Two Bosmina Species (Cladocera, Crustacea) Co-Existing in a Lake: Their Relationship with Invertebrate Predators. J. Plankton Res. 2003, 25, 141-150. [CrossRef]

9. Deng, D.; Xie, P. Effect of Food and Temperature on the Growth and Development of Moina Irrasa (Cladocera: Moinidae). J. Freshw. Ecol. 2003, 18, 503-513. [CrossRef]

10. Hart, R.C.; Bychek, E.A. Body Size in Freshwater Planktonic Crustaceans: An Overview of Extrinsic Determinants and Modifying Influences of Biotic Interactions. Hydrobiologia 2011, 668, 61-108. [CrossRef]

11. Gillooly, J.F.; Dodson, S.I. Latitudinal Patterns in the Size Distribution and Seasonal Dynamics of New World, Freshwater Cladocerans. Limnol. Oceanogr. 2000, 45, 22-30. [CrossRef]

12. Perrin, N. Why Are Offspring Born Larger When It Is Colder? Phenotypic for Offspring Plasticity Size in the Cladoceran Simocephalus Vetulus (Muller). Funct. Ecol. 1988, 2, 283-288. [CrossRef]

13. Atkinson, D. Temperature and Organism Size-A Law for Ectotherms? Adv. Ecol. Res. 1994, 25, 1-58.

14. Atkinson, D. Effects of Temperature on the Size of Aquatic Ectotherms: Exception to General Rule. J. Therm. Biol. 1995, 20, 61-71. [CrossRef]

15. Smol, J.P. Pollution of Lakes and Rivers; Blackwell Publishing: Oxford, UK, 2002.

16. Flower, R.J. Diatom Preservation: Experiments and Observations on Dissolution and Breakage in Modern and Fossil Material. Hydrobiologia 1993, 269-270, 473-484. [CrossRef]

17. Battarbee, R.W.; Anderson, N.J.; Jeppesen, E.; Leavitt, P.R. Combining Palaeolimnological and Limnological Approaches in Assessing Lake Ecosystem Response to Nutrient Reduction. Freshw. Biol. 2005, 50, 1772-1780. [CrossRef]

18. Kattel, G.R.; Battarbee, R.W.; Mackay, A.W.; Birks, H.J.B. Recent Ecological Change in a Remote Scottish Mountain Loch: An Evaluation of a Cladocera-Based Temperature Transfer-Function. Palaeogeogr. Palaeoclimatol. Palaeoecol. 2008, 259, 51-76. [CrossRef]

19. López-Blanco, C.; Miracle, M.R.; Vicente, E. Cladoceran Assemblages in a Karstic Lake as Indicators of Hydrological Alterations. Hydrobiologia 2011, 676, 249-261. [CrossRef]

20. Korhola, A.; Rautio, M. 2. Cladocera and Other Branchiopod Crustaceans. In Tracking Environmental Change Using Lake Sediments. Volume 4: Zoological Indicators; Smol, J.P., Birks, H.J.B., Last, W.M., Eds.; Kluwer Academic Publishers: Dordrecht, The Netherlands, 2001; pp. 5-41. [CrossRef]

21. Jeppesen, E.; Leavitt, P.; De Meester, L.; Jensen, J.P. Functional Ecology and Palaeolimnology: Using Cladoceran Remains to Reconstruct Anthropogenic Impact. Trends Ecol. Evol. 2001, 16, 191-198. [CrossRef]

22. Jeppesen, E.; Nõges, P.; Davidson, T.A.; Haberman, J.; Nõges, T.; Blank, K.; Lauridsen, T.L.; Søndergaard, M.; Sayer, C.; Laugaste, R.; et al. Zooplankton as Indicators in Lakes: A Scientific-Based Plea for Including Zooplankton in the Ecological Quality Assessment of Lakes According to the European Water Framework Directive (WFD). Hydrobiologia 2011, 676, 279-297. [CrossRef]

23. Korosi, J.B.; Paterson, A.M.; Desellas, A.M.; Smol, J.P. Linking Mean Body Size of Pelagic Cladocera to Environmental Variables in Precambrian Shield Lakes: A Paleolimnological Approach. J. Limnol. 2008, 67, 22-34. [CrossRef]

24. Bjerring, R.; Becares, E.; Declerck, S.; Gross, E.M.; Hansson, L.-A.; Kairesalo, T.; Nykänen, M.; Halkiewicz, A.; Kornijów, R.; Conde-Porcuna, J.M.; et al. Subfossil Cladocera in Relation to Contemporary Environmental Variables in 54 Pan-European Lakes. Freshw. Biol. 2009, 54, 2401-2417. [CrossRef] 
25. Korponai, J.; Magyari, E.K.; Buczkó, K.; Iepure, S.; Namiotko, T.; Czakó, D.; Kövér, C.; Braun, M. Cladocera Response to Late Glacial to Early Holocene Climate Change in a South Carpathian Mountain Lake. Hydrobiologia 2011, 676, 223-235. [CrossRef]

26. Nevalainen, L.; Luoto, T.P.; Kultti, S.; Sarmaja-Korjonen, K. Spatio-Temporal Distribution of Sedimentary Cladocera (Crustacea: Branchiopoda) in Relation to Climate. J. Biogeogr. 2013, 40, 1548-1559. [CrossRef]

27. Nevalainen, L.; Rantala, M.V.; Luoto, T.P. Sedimentary Cladoceran Assemblages and Their Functional Attributes Record Late Holocene Climate Variability in Southern Finland. J. Paleolimnol. 2015, 1-14. [CrossRef]

28. Burks, R.L.; Lodge, D.M.; Jeppesen, E.; Lauridsen, T.L. Diel Horizontal Migration of Zooplankton: Costs and Benefits of Inhabiting the Littoral. Freshw. Biol. 2002, 47, 343-365. [CrossRef]

29. Sagrario, G.; de los Ángeles, M.; Balseiro, E.; Ituarte, R.; Spivak, E. Macrophytes as Refuge or Risky Area for Zooplankton: A Balance Set by Littoral Predacious Macroinvertebrates. Freshw. Biol. 2009, 54, 1042-1053. [CrossRef]

30. Jeppesen, E.; Jensen, J.P.; Søndergaard, M.; Lauridsen, T.; Pedersen, L.J.; Jensen, L. Top-down Control in Freshwater Lakes: The Role of Nutrient State, Submerged Macrophytes and Water Depth. Hydrobiologia 1997, 342, 151-164. [CrossRef]

31. De Los Ángeles, M.; Sagrario, G.; Balseiro, E. The Role of Macroinvertebrates and Fish in Regulating the Provision by Macrophytes of Refugia for Zooplankton in a Warm Temperate Shallow Lake. Freshw. Biol. 2010, 55, 2153-2166. [CrossRef]

32. Jeppesen, E.; Søndergaard, M.; Søndergaard, M.; Christoffersen, K. The Structuring Role of Submerged Macrophytes in Lakes; Jeppesen, E., Søndergaard, M., Søndergaard, M., Christoffersen, K., Eds.; Ecological Studies; Springer: New York, NY, USA, 1998; Volume 131. [CrossRef]

33. Scheffer, M. Ecology of Shallow Lakes; Springer: Dordrecht, The Netherlands, 2004. [CrossRef]

34. Płaska, W.; Mieczan, T. Effects of Water Bugs on Crustacean Zooplankton in a Shallow Littoral Zone. Knowl. Manag. Aquat. Ecosyst. 2018. [CrossRef]

35. Adamczuk, M. The Effect of Habitat Complexity on the Contribution of Some Littoral-Benthic Cladocera to the Pelagic Food Web. Mar. Freshw.Res. 2013, 64, 1049-1057. [CrossRef]

36. Adamczuk, M. Niche Separation by Littoral-Benthic Chydoridae (Cladocera, Crustacea) in a Deep Lake-Potential Drivers of Their Distribution and Role in Littoral-Pelagic Coupling. J. Limnol. 2014, 73, 490-501. [CrossRef]

37. Choedchim, W.; Damme, K.; Van Maiphae, S. Spatial and Temporal Variation of Cladocera in a Tropical Shallow Lake. Ann. Limnol. 2017, 53, 233-252. [CrossRef]

38. Basińska, A.M.; Antczak, M.; Świdnicki, K.; Jassey, V.E.J.; Kuczyńska-Kippen, N. Habitat Type as Strongest Predictor of the Body Size Distribution of Chydorus Sphaericus (O. F. Müller) in Small Water Bodies. Int. Rev. Hydrobiol. 2014, 99, 382-392. [CrossRef]

39. Rivera-De la Parra, L.; Sarma, S.S.S.; Nandini, S. Effects of Predation by Hydra (Cnidaria) on Cladocerans (Crustacea: Cladocera). J. Limnol. 2016, 75 (Suppl. 1), 39-47. [CrossRef]

40. Rabus, M.; Söllradl, T.; Clausen-Schaumann, H.; Laforsch, C. Uncovering Ultrastructural Defences in Daphnia Magna-An Interdisciplinary Approach to Assess the Predator-Induced Fortification of the Carapace. PLoS ONE 2013, 8, e67856. [CrossRef]

41. Laforsch, C.; Ngwa, W.; Grill, W.; Tollrian, R. An Acoustic Microscopy Technique Reveals Hidden Morphological Defenses in Daphnia. Proc. Natl. Acad. Sci. USA 2004, 101, 15911-15914. [CrossRef]

42. Rizo, E.Z.; Xu, S.; Tang, Q.; Papa, R.D.S.; Dumont, H.J.; Qian, S.S.; Han, B.P. A Global Analysis of Cladoceran Body Size and Its Variation Linking to Habitat, Distribution and Taxonomy. Zool. J. Linn. Soc. 2019, 187, 1119-1130. [CrossRef]

43. Pirinen, P.; Simola, H.; Aalto, J.; Kaukoranta, J.-P.; Karlsson, P.; Ruuhela, R. Tilastoja Suomen Ilmastosta 1981-2010; Ilmatieteen laitos: Helsinki, Finland, 2012; Volume 1.

44. Korponai, J.; Varga, K.A.; Lengré, T.; Papp, I.; Tóth, A.; Braun, M. Paleolimnological Reconstruction of the Trophic State in Lake Balaton (Hungary) Using Cladocera Remains. Hydrobiologia 2011, 676, 237-248. [CrossRef]

45. Livingstone, D.M.; Lotter, A.F. The Relationship between Air and Water Temperatures in Lakes of the Swiss Plateau: A Case Study with Palæolimnological Implications. J. Paleolimnol. 1998, 19, 181-198. [CrossRef] 
46. Livingstone, D.M.; Padisák, J. Large-Scale Coherence in the Response of Lake Surface-Water Temperatures to Synoptic-Scale Climate Forcing during Summer. Limnol. Oceanogr. 2007, 52, 896-902. [CrossRef]

47. Hijmans, R.J.; Cameron, S.E.; Parra, J.L.; Jones, P.G.; Jarvis, A. Very High Resolution Interpolated Climate Surfaces for Global Land Areas. Int. J. Climatol. 2005, 25, 1965-1978. [CrossRef]

48. Hijmans, R.J.; Phillips, S.; Leathwick, J.; Elith, J. Dismo: Species Distribution Modeling; 2016.

49. Fick, S.E.; Hijmans, R.J. WorldClim 2: New 1-Km Spatial Resolution Climate Surfaces for Global Land Areas. Int. J. Climatol. 2017, 37, 4302-4315. [CrossRef]

50. Szeroczyńska, K.; Sarmaja-Korjonen, K. Atlas of Subfossil Cladocera from Central and Northern Europe; Friends of Lower Vistula Society: Swiecie, Poland, 2007.

51. Pohlert, T. Package 'PMCMRplus': Calculate Pairwise Cultiple Comparisons of Mean Rank Sums Extended; R-Project: Vienna, Austria, 2018.

52. R Core Team. R: A Language and Environment for Statistical Computing; R Core Team: Vienna, Austria, 2015.

53. Gamble, A.E.; Lloyd, R.; Aiken, J.; Johannsson, O.E.; Mills, E.L. Using Zooplankton Biomass Size Spectra to Assess Ecological Change in a Well-Studied Freshwater Lake Ecosystem: Oneida Lake, New York. Can. J. Fish. Aquat. Sci. 2006, 63, 2687-2699. [CrossRef]

54. Brooks, J.L.; Dodson, S.I. Predation, Body Size, and Composition of Plankton. Science 1965, 150, $28-35$. [CrossRef]

55. Cousyn, C.; De Meester, L.; Colbourne, J.K.; Brendonck, L.; Verschuren, D.; Volckaert, F. Rapid, Local Adaptation of Zooplankton Behavior to Changes in Predation Pressure in the Absence of Neutral Genetic Changes. Proc. Natl. Acad. Sci. USA 2001, 98, 6256-6260. [CrossRef]

56. Sweetman, J.N.; Finney, B.P. Differential Responses of Zooplankton Populations (Bosmina Longirostris) to Fish Predation and Nutrient-Loading in an Introduced and a Natural Sockeye Salmon Nursery Lake on Kodiak Island, Alaska, USA. J. Paleolimnol. 2003, 30, 183-193. [CrossRef]

57. Lotter, A.F.; Birks, H.J.B.; Hofmann, W.; Marchetto, A. Modern Diatom, Cladocera, Chironomid, and Chrysophyte Cyst Assemblages as Quantitative Indicators for the Reconstruction of Past Environmental Conditions in the Alps. I. Climate. J. Paleolimnol. 1997, 18, 395-420. [CrossRef]

58. Manca, M.; Comoli, P. Reconstructing Long-Term Changes in Daphnia's Body Size from Subfossil Remains in Sediments of a Small Lake in the Himalayas. J. Paleolimnol. 2004, 32, 95-107. [CrossRef]

59. Atkinson, D.; Morley, S.A.; Hughes, R.N. From Cells to Colonies: At What Levels of Body Organization Does the "temperature-Size Rule" Apply? Evol. Dev. 2006, 8, 202-214. [CrossRef]

60. Whiteside, M.C.; Williams, J.B.; White, C.P. Seasonal Abundance and Pattern of Chydorid, Cladocera in Mud and Vegetative Habitats. Ecology 1978, 59, 1177-1188. [CrossRef]

61. Tremel, B.; Frey, S.E.L.; Yan, N.D.; Somers, K.M.; Pawson, T.W. Habitat Specificity of Littoral Chydoridae (Crustacea, Branchiopoda, Anomopoda) in Plastic Lake, Ontario, Canada. Hydrobiologia 2000, 432, 195-205. [CrossRef]

62. Smirnov, N. The Chydorinae and Sayciinae (Chydoridae) of the World; Guides to the Identification of the Microinvertebrates of the Continental Waters of the World; SPB Academic: Amsterdam, The Netherlands, 1996.

63. Alonso, M. Crustacea, Branchiopoda, Fauna Iberica. Vol. 7; Museo Nacional de Ciencias Naturales, Consejo Superior de Investigaciones Cientificas: Madrid, Spain, 1996. [CrossRef]

64. Fryer, G. Evolution and Adaptive Radiation in the Chydoridae (Crustacea: Cladocera): A Study in Comparative Functional Morphology and Ecology. Philos. Trans. R. Soc. B Biol. Sci. 1968, 254, 224-387.

65. Van Damme, K.; Brancelj, A.; Dumont, H.J. Adaptations to the Hyporheic in Aloninae (Crustacea: Cladocera): Allocation of Alona Protzi Hartwig, 1900 and Related Species to Phreatalona Gen. Nov. Hydrobiologia 2009, 618,1-34. [CrossRef]

66. Nevalainen, L.; Helama, S.; Luoto, T.P. Hydroclimatic Variations over the Last Millennium in Eastern Finland Disentangled by Fossil Cladocera. Palaeogeogr. Palaeoclimatol. Palaeoecol. 2013, 378, 13-21. [CrossRef]

67. Kingsolver, J.G.; Huey, R.B. Size, Temperature, and Fitness: Three Rules. Evol. Ecol. Res. 2008, 10, $251-268$.

68. Pop, M. Mechanisms of the Filtering Area Adaptation in Daphnia. Hydrobiologia 1991, 225, 169-176. [CrossRef]

69. Macháček, J.; Seda, J. Over-Wintering Daphnia: Uncoupling the Effects of Temperature and Food on Offspring Size and Filtering Screen Morphology in D. Galeata. J. Plankton Res. 2013, 35, 1069-1079. [CrossRef]

70. Gliwicz, Z.M. Food Thresholds and Body Size in Cladocerans. Nature 1990, 343, 638-640. [CrossRef]

71. Lampert, W. Phenotypic Plasticity of the Filter Screen in Daphnia: Adapatation to a Low-Food Environment. Limnol. Oceanogr. 1994, 39, 997-1006. [CrossRef] 
72. Repka, S.; Veen, A.; Vijverberg, J. Morphological Adaptations in Filtering Screens of Daphnia Galeata to Food Quantity and Food Quality. J. Plankton Res. 1999, 21, 971-989. [CrossRef]

73. Boersma, M.; Boriss, H.; Mitchell, S.E. Maternal Effects after Sexual Reproduction in Daphnia Magna. J. Plankton Res. 2000, 22, 279-285. [CrossRef]

74. Bergmann, C. Über die Verhältnisse der Wärmeökonomie der Thiere zu ihrer Grösse; Verlagsort: Göttingen, Germany, 1848.

75. Forster, J.; Hirst, A.G.; Atkinson, D. Warming-Induced Reductions in Body Size Are Greater in Aquatic than Terrestrial Species. Proc. Natl. Acad. Sci. USA 2012, 109, 19310-19314. [CrossRef]

76. Horne, C.R.; Hirst, A.G.; Atkinson, D. Temperature-Size Responses Match Latitudinal-Size Clines in Arthropods, Revealing Critical Differences between Aquatic and Terrestrial Species. Ecol. Lett. 2015. [CrossRef] [PubMed]

77. Angilletta, M.J.; Steury, T.D.; Sears, M.W. Temperature, Growth Rate, and Body Size in Ectotherms: Fitting Pieces of a Puzzle. Integr. Comp. Biol. 2004, 44, 498-509. [CrossRef] [PubMed]

78. Karpowicz, M.; Ejsmont-Karabin, J.; Kozłowska, J.; Feniova, I.; Dzialowski, A.R. Zooplankton Community Responses to Oxygen Stress. Water 2020, 12, 706. [CrossRef]

79. Verberk, W.C.E.P.; Bilton, D.T.; Calosi, P.; Spicer, J.I. Oxygen Supply in Aquatic Ectotherms: Partial Pressure and Solubility Together Explain Biodiversity and Size Patterns. Ecology 2011, 92, 1565-1572. [CrossRef]

80. Verberk, W.C.E.P.; Atkinson, D. Why Polar Gigantism and Palaeozoic Gigantism Are Not Equivalent: Effects of Oxygen and Temperature on the Body Size of Ectotherms. Funct. Ecol. 2013, 27, 1275-1285. [CrossRef]

81. Fang, X.; Stefan, G. Temperature Variability in Lake Sediments Depth. Water Resour. 1998, 34, 717-729. [CrossRef]

82. Salmaso, N. Effects of Climatic Fluctuations and Vertical Mixing on the Interannual Trophic Variability of Lake Garda, Italy. Limnol. Oceanogr. 2005, 50, 553-565. [CrossRef]

83. Luoto, T.P. Hydrological Change in Lakes Inferred from Midge Assemblages through Use of an Intralake Calibration Set. Ecol. Monogr. 2010, 80, 303-329. [CrossRef]

84. Luoto, T.P. Intra-Lake Patterns of Aquatic Insect and Mite Remains. J. Paleolimnol. 2012, 47, 141-157. [CrossRef]

85. Nykänen, M.; Kairesalo, T.; Mäkelä, S.; Huitu, E.; Ala-Opas, P.; Mannio, J. A Typology and Ecological Classification System for Finnish Lakes: Applicability of the ECOFRAME Scheme. Boreal Environ. Res. 2005, 10, 159-179.

86. Decei, P. Lacuri de Munte. Drumetie Si Pescuit; Ditura Sport Turism: Bucharest, Romania, 1981.

87. Frost, W.E. The Natural History of the Minnow, Phoxinus Phoxinus. J. Anim. Ecol. 1943, 12, $139-162$. [CrossRef]

88. Straskraba, M.; Chiar, J.; Frank, S.; Hruska, V. Contribution to the Problem of Food Competition among the Sculpin, Minnow and Brown-Trout. J. Anim. Ecol. 1966, 35, 303-311. [CrossRef]

89. Museth, J.; Borgstrøm, R.; Brittain, J.E. Diet Overlap between Introduced European Minnow (Phoxinus Phoxinus) and Young Brown Trout (Salmo Trutta) in the Lake, Øvre Heimdalsvatn: A Result of Abundant Resources or Forced Niche Overlap? Hydrobiologia 2010, 642, 93-100. [CrossRef]

90. Rautio, M.; Vincent, W.F. Benthic and Pelagic Food Resources for Zooplankton in Shallow High-Latitude Lakes and Ponds. Freshw. Biol. 2006, 51, 1038-1052. [CrossRef]

91. Milardi, M.; Siitonen, S.; Lappalainen, J.; Liljendahl, A.; Weckström, J. The Impact of Trout Introductions on Macro- and Micro-Invertebrate Communities of Fishless Boreal Lakes. J. Paleolimnol. 2016, 55, $273-287$. [CrossRef]

92. Helminen, H.; Karjalainen, J.; Kurkilahti, M.; Rask, M.; Sarvala, J. Eutrophication and Fish Biodiversity in Finnish Lakes. Verh. Int. Ver. Theor. Angew. Limnol. 2000, 27, 194-199. [CrossRef]

93. Moss, B.; Stephen, D.; Alvarez, C.; Becares, E.; Van De Bund, W.; Collings, S.E.; Van Donk, E.; De Eyto, E.; Feldmann, T.; Fernández-Aláez, C.; et al. The Determination of Ecological Status in Shallow Lakes-A Tested System (ECOFRAME) for Implementation of the European Water Framework Directive. Aquat. Conserv. Mar. Freshw. Ecosyst. 2003, 13, 507-549. [CrossRef]

94. Belyaeva, M.; Taylor, D.J. Cryptic Species within the Chydorus Sphaericus Species Complex (Crustacea: Cladocera) Revealed by Molecular Markers and Sexual Stage Morphology. Mol. Phylogenet. Evol. 2009, 50, 534-546. [CrossRef] [PubMed] 
95. Frey, D.G. On the Plurality of Chydorus Sphaericus (0. F. Müller) (Cladocera, Chydoridae), and Designation of a Neotype from Sjaelsø, Denmark. Hydrobiologia 1980, 69, 83-123. [CrossRef]

96. Van Damme, K.; Eggermont, H. The Afromontane Cladocera (Crustacea: Branchiopoda) of the Rwenzori (Uganda-D. R. Congo): Taxonomy, Ecology and Biogeography. Hydrobiologia 2011, 676, 57-100. [CrossRef] 